\title{
Microplastics in freshwater fishes: Occurrence, impacts and future perspectives
}

\author{
Ben Parker (iD | Demetra Andreou (iD | lain D. Green (iD | J. Robert Britton
}

Department of Life and Environmental Sciences, Faculty of Science and Technology, Bournemouth University, Poole, UK

\section{Correspondence}

Ben Parker, Department of Life and Environmental Sciences, Faculty of Science and Technology, Bournemouth University, Poole, Dorset BH12 5BB, UK.

Email: bparker@bournemouth.ac.uk

Funding information

Fisheries Society of the British Isles, Grant/Award Number: FSBI-funded PhD Studentship

\begin{abstract}
Microplastics (MPs) are small, plastic particles of various shapes, sizes and polymers. Although well studied in marine systems, their roles and importance in freshwater environments remain uncertain. Nevertheless, the restricted ranges and variable traits of freshwater fishes result in their communities being important receptors and strong bioindicators of MP pollution. Here, the current knowledge on MPs in freshwater fishes is synthesized, along with the development of recommendations for future research and sample processing. MPs are commonly ingested and passively taken up by numerous freshwater fishes, with ingestion patterns often related to individual traits (e.g. body size, trophic level) and environmental factors (e.g. local urbanization, habitat features). Controlled MP exposure studies highlight various effects on fish physiology, biochemistry and behaviour that are often complex, unpredictable, species-specific and nonlinear in respect of dose-response relationships. Egestion is typically rapid and effective, although particles of a particular shape and/ or size may remain, or translocate across the intestinal wall to other organs via the blood. Regarding future studies, there is a need to understand the interactions of MP pollution with other anthropogenic stressors (e.g. warming, eutrophication), with a concomitant requirement to increase the complexity of studies to enable impact assessment at population, community and ecosystem levels, and to determine whether there are consequences for processes, such as parasite transmission, where MPs could vector parasites or increase infection susceptibility. This knowledge will determine the extent to which MP pollution can be considered a major anthropogenic stressor of freshwaters in this era of global environmental change.
\end{abstract}

\section{KEYWORDS}

anthropogenic stressors, bioindicators, effects, egestion, exposure, ingestion

\section{1 | INTRODUCTION}

\section{1 | Microplastics in the environment}

The ubiquity of microplastics (MPs), small plastics particles $<5 \mathrm{~mm}$ in diameter (Barnes et al., 2009), has recently developed into an environmental issue of high societal concern, especially as MP pollution is intricately linked to the use of plastics in everyday life (Rodrigues et al., 2019). Primary MPs are deliberately manufactured within this general size range for use in industry or various cosmetic products (Godoy et al., 2019; Guerranti et al., 2019; Yurtsever, 2019), whereas secondary MPs form from the breakdown of larger plastics

This is an open access article under the terms of the Creative Commons Attribution License, which permits use, distribution and reproduction in any medium, provided the original work is properly cited.

(C) 2021 The Authors. Fish and Fisheries published by John Wiley \& Sons Ltd. 
through physical, chemical and biological degradation (Kundungal et al., 2019; Raddadi \& Fava, 2019; Sánchez, 2019; Winkler et al., 2019).

Microplastics are highly diverse and vary in size, shape, colour, polymer type and their constituent chemicals that all affect how they behave in the environment (e.g. their transport, degradation, adsorption capacity and ultimate fate). Nevertheless, variants of polyethylene (PE), polypropylene (PP), polyethylene terephthalate (PET), polystyrene (PS) and polyvinyl chloride (PVC) account for $90 \%$ of all plastic polymers used (Andrady \& Neal, 2009) and, therefore, most MPs also. All MPs can be considered as dynamic, being continually modified and degraded over time to produce ever smaller particles, eventually forming nanoplastics (NPs) $<1 \mu \mathrm{m}$ (Gigault et al., 2018).

Microplastics were identified within the marine environment in the 1970s (Carpenter et al., 1972; Carpenter \& Smith, 1972), though the term was introduced later by Thompson et al. (2004), with many studies subsequently identifying MPs in freshwater and terrestrial systems, where both water (Akdogan \& Guven, 2019; Bank \& Hansson, 2019; Wu et al., 2019) and wind (Chen et al., 2020; Huang, Qing, et al., 2020; Zhang et al., 2019) are major transport mechanisms. Several studies have also highlighted that waste plastics, including MPs, in aquatic systems typically originate from the land, demonstrating the interconnectedness of aquatic and terrestrial systems (Malizia \& Monmany-Garzia, 2019; de Souza Machado et al., 2018).

Plastic particles move throughout aquatic systems and float, sink or settle depending on particle properties (density, shape etc.), environmental features (water density, salinity, flow rate etc.) and aquatic processes (e.g. water currents and storm events) (Bondelind et al., 2020; Li, Zhang, et al., 2020). The ultimate fate of MPs is to accumulate in sinks, such as river sediments (SimonSánchez et al., 2019; de Villiers, 2019). MPs may also become temporarily or permanently trapped within algal mats (Feng et al., 2020) or by physical barriers such as dams (Watkins et al., 2019). Environmental perturbations, such as flooding, weather events and habitat alterations, can then free previously trapped or sunk MPs into the environment, which then gradually pass through aquatic systems and biota (von Friesen et al., 2020; O'Connor et al., 2019; Ockelford et al., 2020).

Studies on ingestion reveal that environmental MPs are consumed by a range of different taxa across varying trophic positions (TPs), feeding types and habitats (Gouin, 2020; Ribeiro et al., 2019). Many of these studies have focused on marine organisms, especially taxa of ecological, economic or conservation interest (Casabianca et al., 2019; Katyal et al., 2020; Setälä et al., 2014; Ward et al., 2019). A secondary goal is often trying to understand the potential human exposure via ingestion of contaminated fauna (Oliveira et al., 2019; Prata et al., 2020; Rainieri \& Barranco, 2019; Walkinshaw et al., 2020). Complementary studies have focused on developing understandings of how MP exposure affects animal physiology, population dynamics, ecology and behaviour (Anbumani \& Kakkar, 2018; Franzellitti et al., 2019; Guzzetti et al., 2018; Prokić et al., 2019). Although the main research focus has been on marine species

\begin{tabular}{|c|c|}
\hline 1. INTRODUCTION & 467 \\
\hline 1.1. Microplastics in the environment & 467 \\
\hline 1.2. Issues of MPs in freshwaters and freshwater fishes & 468 \\
\hline $\begin{array}{l}\text { 2. OCCURRENCE OF MPS IN FRESHWATER FISHES: } \\
\text { FROM SOURCES TO EGESTION }\end{array}$ & 468 \\
\hline 2.1. Sources of freshwater MPs & 469 \\
\hline 2.2. Transport of MPs in freshwater & 470 \\
\hline 2.3. MP encounter rates in freshwater fishes & 470 \\
\hline 2.4. MP ingestion by freshwater fish & 471 \\
\hline 2.5. MP processing and egestion & 473 \\
\hline $\begin{array}{l}\text { 3. IMPACTS OF INGESTED MPS ON FRESHWATER } \\
\text { FISHES }\end{array}$ & 474 \\
\hline 3.1. Physiological impacts & 474 \\
\hline 3.2. Biological consequences & 475 \\
\hline 3.3. MPs as biological vectors & 476 \\
\hline 4. FUTURE PERSPECTIVES & 477 \\
\hline 4.1. Experimental approaches & 477 \\
\hline 4.2. Nonfatal field sampling & 477 \\
\hline 4.3. Laboratory analyses & 478 \\
\hline 4.4. Scaling up complexity & 478 \\
\hline 5. CONCLUSIONS & 478 \\
\hline ACKNOWLEDGEMENTS & 479 \\
\hline DATA AVAILABILITY STATEMENT & 479 \\
\hline REFERENCES & 479 \\
\hline
\end{tabular}

and systems, there is increasing knowledge on how MPs behave and their consequent effects in freshwater (Li et al., 2018; Strungaru et al., 2019; Triebskorn et al., 2019).

\section{2 | Issues of MPs in freshwaters and freshwater fishes}

Though covering only a relatively small proportion of the surface of the earth $(<0.01 \%)$, freshwaters are highly biodiverse and support a wide range of key ecosystem services (Dodds et al., 2013). They are also already at high risk from multiple anthropogenic stressors, including nutrient pollution, habitat loss, biological invasions and climate change (Jackson et al., 2016; Ormerod et al., 2010; Reid et al., 2019). Consequently, freshwater MPs potentially represent an additional stressor, with freshwater environments also representing a critical target habitat for future MP remediation and mitigation strategies (Karbalaei et al., 2018; Wong, Lee, et al., 2020). As much as $80 \%$ of aquatic plastic waste originates from terrestrial sources (Andrady, 2011) and often reaches marine environments via connecting freshwaters (Galloway et al., 2017).

Freshwater fishes comprise a highly diverse taxonomic group, covering a range of TPs, ecological guilds and life history strategies (Noble et al., 2007). With the exception of diadromous fishes, they spend their lives within a limited area, where the presence of anthropogenic barriers may further limit 
their range (Grill et al., 2019). Thus, freshwater fish populations and communities may be continuously exposed to a range of MPs throughout their lives and must adapt to, or tolerate all changes within their local environment, particularly where their movement is restricted. Freshwater fish are, therefore, a key receptor and bioindicator of MP pollution and so represent strong model taxa for developing knowledge on how MPs affect the ecology and behaviour of animals, from individuals through to community levels. Consequently, in this review, we synthesize the issues and knowledge gaps relating to MPs in freshwater fishes and suggest future research directions and approaches. The objectives of this knowledge synthesis are to: (a) summarize the major sources of and transport of MPs into freshwaters; (b) outline the major ingestion-egestion and processing pathways within freshwater fish; (c) detail the principal impacts of MPs on freshwater fish; and (d) outline a series of future perspectives on research priorities and approaches. Figure 1, below, summarizes the sources, transport, processes and pathways relating to MPs in freshwater fish discussed in this review.

\section{I OCCURRENCE OF MPS IN FRESHWATER FISHES: FROM SOURCES TO EGESTION}

\section{1 | Sources of freshwater MPs}

Most freshwater MPs originate from terrestrial systems (Andrady, 2011), with the extent of local urbanization being a strong predictor of MP loadings in nearby water bodies, which are dependent on, and also a proxy of, local plastic usage and disposal (Kataoka et al., 2019; Tibbetts et al., 2018). The breakdown of larger plastic materials (including paints, tyres and litter) by physical, chemical and biological processes is an important source of secondary MPs to freshwaters (Fadare et al., 2020; Horton et al., 2017; Karbalaei et al., 2018; Knight

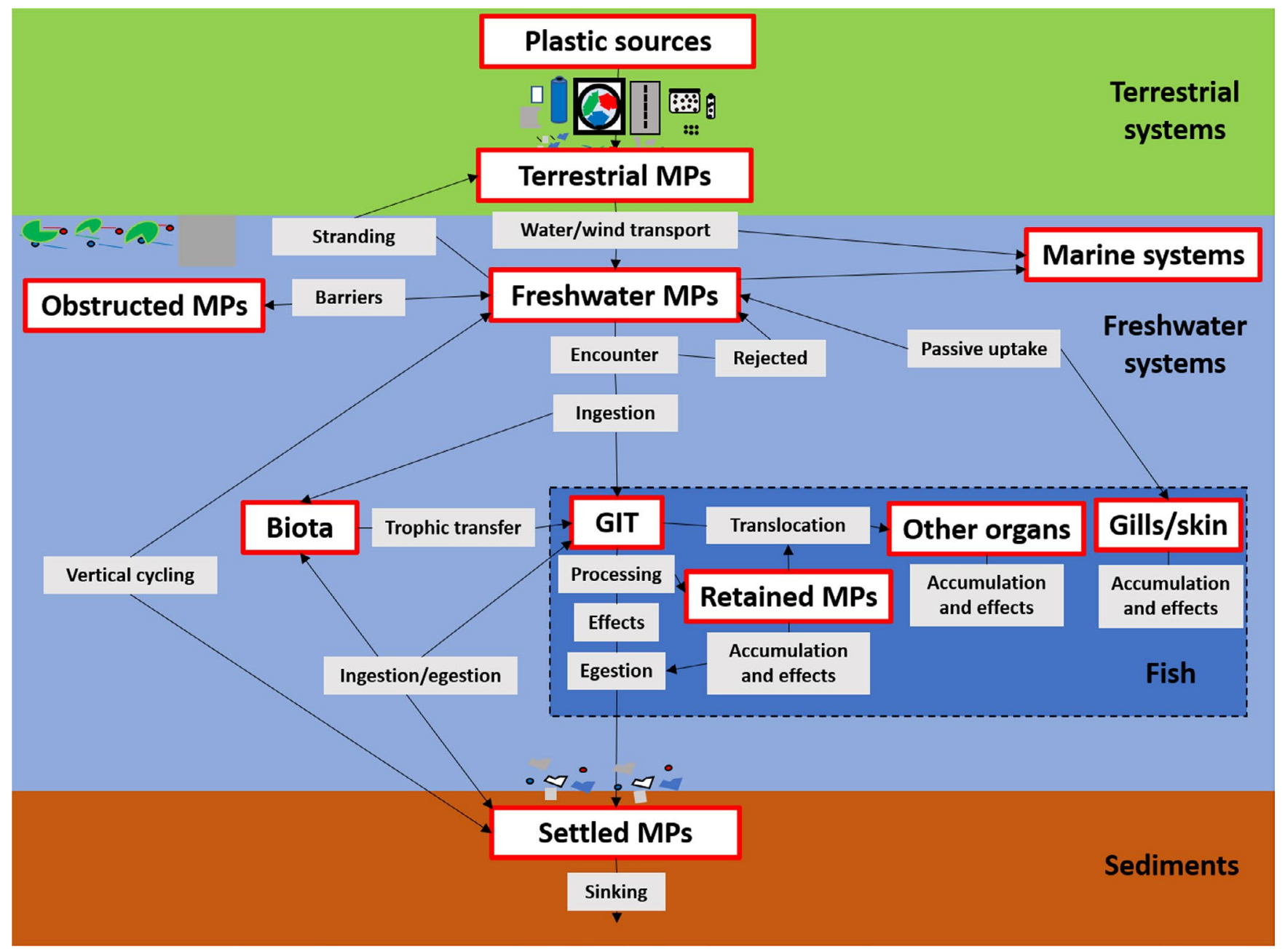

FIGURE 1 Generalized overview of microplastics in freshwater fishes including sources, transport and transfer between different biota and systems. Grey boxes indicate processes, red outlined boxes indicate abiotic and biotic compartments and arrows indicate the directionality of microplastic transfer. "MPs" is used as an abbreviation for microplastics and "GIT" for the gastrointestinal tract. [Colour figure can be viewed at wileyonlinelibrary.com] 
et al., 2020). Recreational freshwater activities such as boating and angling may also contribute MPs or larger plastic waste directly into rivers and lakes through the degradation of plastic lines, nets, boats, waders etc.; however, these potential sources have yet to be investigated and quantified. MPs, along with larger litter, accumulate on impermeable surfaces or in dusts, and are washed into storm drains then water courses after sufficient rain (Liu, Li, et al., 2019; Roychand \& Pramanik, 2020; Yukioka et al., 2019). Some MPs and smaller litter may also be transported by the wind and deposited in various urbanized or remote environments, where dispersal tends to be higher for smaller and lighter particles, particularly fibres (Chen et al., 2020; Huang, Qing, et al., 2020; Y. Zhang et al., 2019; Zhang et al., 2020).

The textile industry is another source of MP pollution as synthetic polymers such as polyester are commonly used to make clothing. The different synthetic materials used as well as the particular manufacturing process may dictate the sustainability and lifespan of the item of clothing (Janaina et al., 2020) and how many secondary MPs, typically fibres, are shed when the item is worn or washed (Belzagui et al., 2019; Henry et al., 2019; Hernandez et al., 2017; Napper \& Thompson, 2016). Aspects of the wash cycle, the machine and the washed load may also impact both the number and type of fibres released (Cai et al., 2020; De Falco et al., 2019; Yang et al., 2019). Synthetic fibres from clothes washing, together with rinsed cosmetics and other flushable plastics (Guerranti et al., 2019; Morritt et al., 2014), then navigate the sewage system within wastewater.

This wastewater eventually passes through the sewage system to wastewater treatment plants (WWTPs), which treat domestic and industrial waste before release into the natural environment (often rivers and estuaries) (Ngo et al., 2019). Waste may undergo biological, chemical and physical processing to remove large debris, neutralize harmful chemicals and degrade biological materials, with these processes simultaneously degrading and modifying MPs throughout treatment (Enfrin et al., 2019; $\mathrm{Li}$, Mei, et al., 2019). Furthermore, there is evidence that MPs may reduce the efficiency of the treatment processes if they contain harmful internal or bound chemicals that can inhibit biological processing stages (Zhang \& Chen, 2019). While WWTPs vary in their treatment processes, even highly efficient WWTPs that approach 98\% MP removal/exclusion still allow the daily discharge of substantial numbers of MPs in treated sewage effluents (Conley et al., 2019; Hidayaturrahman \& Lee, 2019; Hyesung Lee \& Kim, 2018). Waste sludge may accumulate up to $98 \%$ of MPs from the treated water (Gies et al., 2018; Nizzetto et al., 2016), which can account for up to $3 \%$ of biowaste by weight (Mohajerani \& Karabatak, 2020), and is often modified for use as fertilizer if it is not incinerated or disposed at landfill (Edo et al., 2020; Rolsky et al., 2020). Agricultural application thereby provides a secondary opportunity for these MPs to directly reach water courses through runoff, wind dispersal and deposition, together with any MP-bound or internalized chemicals.

\section{2 | Transport of MPs in freshwater}

Microplastics in freshwaters tend to move and behave according to plastic particle properties such as size, shape or polymer density as well as features and processes within the system (Bondelind et al., 2020; Figure 1). MPs may be transported floating, in the water column or carried along the bottom sediments and may have variable residence times in the environment, depending on whether MPs are ingested, impeded or sink and settle onto or into bottom sediments (Daily \& Hoffman, 2020; Hoellein et al., 2019; Song, JongmansHochschulz, et al., 2020). Flow conditions and sediment type can often favour MP accumulation within the sediments, even for particles with relatively low polymer densities, resulting in concentrations often exceeding those of the overlaying surface waters (Frei et al., 2019; Simon-Sánchez et al., 2019; de Villiers, 2019).

Microplastics trapped within sediments may eventually permeate into groundwaters or aquifers before re-joining the water cycle (O'Connor et al., 2019; Re, 2019), or may be freed by storm and rain events that may resuspend trapped MPs and introduce them back into aquatic systems (Bondelind et al., 2020; Ockelford et al., 2020; Piñon-Colin et al., 2020). Since freshwater and climatic factors may vary seasonally, there can also be some temporal variation, with environmental MP loadings typically being higher during wet seasons (Campanale et al., 2019; Eo et al., 2019; Kurniawan \& Imron, 2019; Weideman et al., 2019; Yuan et al., 2019). Meandering and differences in flow and sediment profiles within systems can also produce spatial differences in MP concentrations between the littoral and mid-channel areas of rivers (Wong, Löwemark, et al., 2020). The same processes also largely affect lakes and ponds, though MPs may persist in static water bodies for longer (Daily \& Hoffman, 2020).

The high surface area to volume ratio, the degree of hydrophobicity and the surface structure of MPs may promote the colonization of plastic particles by various microorganisms within natural aquatic systems, altering particle density and interactions with biota and other surfaces (Caruso, 2019; Shen et al., 2019). Degradation and modification of MPs in aquatic systems may also favour the release of internal chemicals (e.g. additives, plasticizers) and/or the binding of various organic and inorganic chemicals present in the environment (e.g. metals, pharmaceuticals, fungicides) depending on environmental conditions, local concentration and MP properties (Caruso, 2019; Godoy et al., 2020; Liu, Zhu, et al., 2019; Magadini et al., 2020; Wang, Yang, et al., 2019). The modification of and binding by MPs in turn impact their transport, density and effects.

\subsection{MP encounter rates in freshwater fishes}

As ectotherms, fish activities and feeding rates are intrinsically linked to the environmental temperature, but will also vary according to the size, sex and metabolic activity of individuals, as well as the abundance, nutritional quality and processing time of their prey resources (Jobling, 1981). Consequently, these same factors may also govern the encounter and ingestion rates of MPs by fish. Although MP encounter by fish is assumed to occur mainly during active feeding, there is increasing evidence of MPs being encountered via the gills and/or epidermis of wild freshwater fish (Abbasi et al., 2018; Hurt et al., 2020; Park et al., 2020). Experimental studies have also 
demonstrated MP accumulation on the gills (Mak et al., 2019; Roch et al., 2020). Passive uptake of MPs is thus an additional source of MPs following environmental exposure during swimming and respiration. Collard et al. (2017) quantified the ingestion of anthropogenic particles in several marine fishes and found that ingestion was highest in the species with the most efficient filtration apparatus (high filtration area and small gill raker spacing). In a similar way, fish features such as gill surface area, gill structure, habitat etc. may correlate with numbers of MPs on the gills suggesting passive accumulation.

The foraging habitats of freshwater fish should also impact MP encounter rates, given MP distributions and loadings differ, with typically higher loadings in sediments compared to overlaying surface waters (Bondelind et al., 2020; Boucher et al., 2019; Li, Geng, et al., 2019). Consequently, within a given location, pelagic species ought to encounter fewer floating MPs (e.g. less dense fibres and beads) than benthivores, with the latter then potentially encountering higher concentrations of sunk and settled MPs (e.g. denser fragments and films), provided there is also a relatively higher benthic MP concentration. Correspondingly, the trophic level of a fish and feeding guild can also affect MP exposure levels, with obligate piscivores potentially only encountering MPs passively or indirectly via ingested prey, whereas species in other feeding guilds are more likely to directly encounter MPs associated with vegetation or detritus (Hoang \& Felix-Kim, 2020; Kalčíková, 2020; Ribeiro et al., 2019).

\subsection{MP ingestion by freshwater fish}

The ingestion patterns of MPs in freshwater fishes have been well documented (Table 1) and may vary depending on the encounter rate, MP characteristics and whether the particle is externally identified as a nonresource item (Collard et al., 2019; Markic et al., 2020). Gape size constrains the prey and MP sizes a fish can ingest, with larger fish generally having larger maximum particle sizes and/or MP loadings (Dantas et al., 2012; Pegado et al., 2018; Ramos et al., 2012; Ryan et al., 2019), although there are exceptions (McNeish et al., 2018; Slootmaekers et al., 2019; Vendel et al., 2017). A general review of plastic ingestion in animals suggests that body size alone can explain as much as $42 \%$ of variations in plastics consumed by animals and that the ratio of the maximum ingestible plastic size for an animal relative to its body size is approximately 1:20 (Jâms et al., 2020). Sex has also been implicated as a possible explanation for differences in freshwater fish MP patterns (Horton et al., 2018; Su, Nan, et al., 2019), although this might be an artefact of body size, given patterns of sexual dimorphism in fish (Parker, 1992).

The issue of body size is, however, complicated at the individual level, given that ontogenetic dietary shifts facilitate changes in prey items and sizes, which then result in changes in TP (Campbell et al., 2017; Hurt et al., 2020; Khan et al., 2020; McNeish et al., 2018; Roch et al., 2019). With their increased gape, body size, and TP, MPs are potentially accumulated in the gastrointestinal tract (GIT) of apex predators, as demonstrated in populations of largemouth bass
(Micropterus salmoides, Centrarchidae) (Hurt et al., 2020) and northern pike (Esox lucius, Esocidae) (Campbell et al., 2017), which both had higher GIT MP levels compared to fishes of lower TP from the same system. However, pike have also been found to have fewer MPs than other fishes (Roch et al., 2019), suggesting some complexity in the transfer of MPs within food chains and the limitations of current "snapshot" MP screening methods. Moreover, a recent general review of plastic ingestion in animals suggested no evidence of bioaccumulation or biomagnification (Gouin, 2020) where MPs cross the intestinal barrier then translocate into and accumulate within tissues, respectively. It should however be noted that ingestion research to date is heavily biased towards MP accumulation in the GIT which, while inside the body, is considered external as it is continuous with the environment at the mouth and anus, though several studies have identified MP bioaccumulation within the liver, brain and muscle of freshwater fish (Abbasi et al., 2018; Batel et al., 2016; Ding et al., 2020; Su, Nan, et al., 2019). The reported mean MP incidence of $20 \%$, a mean of four particles per individual and a general range of up to 10 pieces per individual (Gouin, 2020) is largely consistent with ingestion studies in freshwater fishes (Table 1). The trophic transfer of MPs has been demonstrated experimentally from water fleas (Daphnia magna, Daphniidae) to fathead minnows (Pimephales promelas, Cyprinidae) (Elizalde-Velázquez et al., 2020), brine shrimp (Artemia sp., Artemiidae) to zebrafish (Danio rerio, Cyprinidae) (Batel et al., 2016) and from tintinnid (Favella sp., Ptychocyclidae) to inland silversides (Menidia beryllina, Atherinopsidae) (Athey et al., 2020). Thus, ingestion of MPs via resource items is a viable transfer mechanism in freshwater fish.

The relationship between fish consumption rates and MP exposure concentration followed a Type II functional response curve in banded tilapia (Tilapia sparrmanii, Cichlidae), with consumption of MPs even at low concentrations (Mbedzi et al., 2019). Experiments have also suggested that the probability of ingestion is elevated where MPs have similar characteristics (appearance, smell and/ or taste) to common prey resources (Roch et al., 2020; de Sá et al., 2015). The ingestion of a red MP fibre by a sight-feeding fish may occur, perhaps due to its similarity to chironomid larvae, whereas the binding or leaching of info-chemicals, such as dimethyl sulphide, can induce ingestion by taste-feeding marine copepods (Procter et al., 2019) and fish (Savoca et al., 2017). While dimethyl sulphide is not present in freshwaters, most likely through an absence of the microorganisms that produce it (Zink \& Pyle, 2019), similar freshwater info-chemicals might be discovered.

The increased ingestion rates of MPs when coupled with a feeding cue is supported by experimental evidence that many fish will readily reject MPs except when they are presented in combination with food items (Kim et al., 2019; de Sá et al., 2015; Xiong et al., 2019). It could also explain why older MPs with altered structures and chemistry might be more likely to be consumed than virgin MPs, given that older MPs tend to degrade, develop biofilms or bind other chemicals over time (Chen, Xiong, et al., 2019; Song, Hou, et al., 2020). The adsorption and uptake of MPs by aquatic plants is another understudied concentrating mechanism that has the potential 
TABLE 1 Overview of studies accessible before the $15^{\text {th }}$ May 2020 investigating microplastic ingestion in at least one wild freshwater fish (including estuarine/temporarily freshwater fish)

\begin{tabular}{|c|c|c|c|c|c|c|}
\hline Species & Country & $N$ & FO & Mean & Polymer(s) & References \\
\hline 2 & Brazil & 569 & 7.9 & - & $(\mathrm{PA})^{\mathrm{a}}$ & Dantas et al. (2012) \\
\hline 1 & France & 186 & 12 & - & - & Sanchez et al. (2014) \\
\hline 4 & Switzerland & 40 & 7.5 & - & - & Faure et al. (2015) \\
\hline 2 & Tanzania & 40 & 20 & - & PE, PU, PET & Biginagwa et al. (2016) \\
\hline 2 & USA & 436 & 45 & 0.8 & - & Peters and Bratton (2016) \\
\hline 1 & South Africa & 70 & 73 & 3.8 & - & Naidoo et al. (2016) \\
\hline 1 & Brazil & 530 & 64.2 & - & - & Ferreira et al. (2016) \\
\hline 2 & Switzerland & 25 & 24 & 1.15 & - & Roch and Brinker (2017) \\
\hline 69 & Brazil & 2,233 & 9 & 1.06 & - & Vendel et al. (2017) \\
\hline 13 & China & 35 & 25.7 & 0.86 & PE, PA & K. Zhang et al. (2017) \\
\hline 5 & Canada & 181 & 73.5 & 3.28 & - & Campbell et al. (2017) \\
\hline 11 & Argentina & 87 & 100 & 19.2 & - & Pazos et al. (2017) \\
\hline 4 & South Africa & 36 & 100 & - & - & Naidoo et al. (2017) \\
\hline 3 & Portugal & 120 & 38 & 1.67 & PE, PP, PET, PA, RAY & Bessa et al. (2018) \\
\hline 3 & Australia & 93 & - & 1.37 & PET, RAY & Halstead et al. (2018) \\
\hline 1 & China & 30 & 60 & 4.3 & $\mathrm{PP}, \mathrm{PE}$ & Cheung et al. (2018) \\
\hline 16 & Brazil & 172 & 26.7 & 0.56 & PE, PVC, PP, PA, PMMA & Andrade et al. (2019) \\
\hline 1 & Canada & 74 & 59 & 1.15 & - & Collicutt et al. (2019) \\
\hline 1 & Belgium & 78 & 9 & 0.1 & PET, EVA, PVC, PP, PVA, PA, CE & Slootmaekers et al. (2019) \\
\hline 2 & China & - & - & 1.7 & PE, PP & Lv et al. (2019) \\
\hline 13 & China & 217 & - & - & PET, PP, PE & Su, Deng, et al. (2019) \\
\hline 2 & Brazil & 529 & $>50$ & $1.4 / 1.5$ & - & Ferreira, Barletta, et al. (2019) \\
\hline 9 & China & 279 & 50 & 7 & PE, PP, PET & Zheng et al. (2019) \\
\hline 1 & China & 11 & 91 & 7.64 & $\mathrm{PE}, \mathrm{PP}$ & Yuan et al. (2019) \\
\hline 1 & Australia & 180 & 19.4 & 0.6 & PET, RAY, PA, PP & Su, Nan, et al. (2019) \\
\hline 3 & Brazil & 529 & 58 & 1.46 & - & Ferreira, Barletta, Lima, Morley, et al., 2019 \\
\hline 1 & USA & 44 & 100 & 9 & - & Ryan et al. (2019) \\
\hline 22 & Germany & 1167 & 18.8 & 0.2 & - & Roch et al. (2019) \\
\hline 1 & Argentina & 21 & 100 & 9.9 & - & Blettler et al. (2019) \\
\hline 2 & USA & 96 & 100 & - & - & Hurt et al. (2020) \\
\hline 2 & Poland & 389 & 54.5 & 1.16 & - & Kuśmierek and Popiołek (2020) \\
\hline 4 & South Africa & 174 & 52 & 0.79 & RAY, PET, PA, PVC & Naidoo et al. (2020) \\
\hline
\end{tabular}


TABLE 1 (Continued)

\begin{tabular}{lllllll} 
Species & Country & N & FO & Mean & Polymer(s) & References \\
\hline 8 & Thailand & 107 & 72.9 & 1.76 & - & Kasamesiri and Thaimuangphol (2020) \\
\hline 32 & China & 120 & $30 / 47$ & 2.83 & PE, PET, PP, PS & Huang, Koongolla, et al. (2020) \\
\hline 6 & South Korea & 6 & 100 & 22 & PFTE, PE, RAY & Park et al. (2020) \\
\hline 2 & Egypt & 43 & 76.7 & 4.91 & PE, PET, PP & Khan et al. (2020) \\
\hline 22 & Colombia & 302 & 7 & 0.23 & PA, EVA, Latex & Garcés-Ordóñez et al. (2020) \\
\hline 4 & China & 126 & - & - & - & Li, Su, et al. (2020) \\
\hline
\end{tabular}

Note: Studies are presented in chronological order. "Species" denotes the number of species studied, "N" the sample size, "FO" the percentage frequency of microplastic occurrence, "Mean" is the mean number of microplastics per individual and "Polymer" lists the main polymers confirmed through chemical techniques.

Alphabetized polymer abbreviations: AC, acrylate; CE, cellophane; EVA, ethylene vinyl acetate; PA, polyamide; PAN, polyacrylonitrile; PE, polyethylene (high or low density); PES, polyethersulphone; PET, polyethylene terephthalate/polyester; PEVA, polyethylene vinyl acetate; PTFE, polytetrafluoroethylene; PMMA, polymethyl methacrylate; PP, polypropylene; PS, polystyrene; PU, polyurethane; PVA, polyvinyl alcohol; PVC, polyvinyl chloride; RAY, rayon.

${ }^{a}$ Denotes studies in which the polymer was reported without chemical confirmation.

to increase the ingestion probability of associated MPs by herbivorous fish (Kalčíková, 2020). Nevertheless, debate remains over important questions such as whether fish are able to distinguish MPs from prey resources and to assess the suitability of MPs as a food source prior to ingestion, if fish learn to avoid or ingest MPs, whether ingestion is deliberate and under which conditions does MP ingestion increase (Huuskonen et al., 2020; Li, Su, et al., 2020; Peters \& Bratton, 2016; Ramos et al., 2012; Ryan et al., 2019).

\section{5 | MP processing and egestion}

Following ingestion, the morphology of both the GIT and ingested MPs may affect their passage through the fish (Jabeen et al., 2017) and whether they temporarily or permanently lodge on to GIT structures, such as coils or projections. Differences in GIT structure have been suggested as a driver of species-specific differences in MP levels (Jabeen et al., 2017), although uncertainty remains over how particular MP morphometrics and physicochemical properties affect their passage rates through fishes and whether there are systematic biases in the MP screening of fish GITs as a consequence.

Internal environments within fish will differ in temperature and $\mathrm{pH}$ which may modify MPs and promote the release of certain harmful MP-associated chemicals (Coffin et al., 2019; Khan et al., 2017; Lee et al., 2019; Wu et al., 2020). These in vitro studies suggest that a variety of chemical and physiological cues in different species and sections of the GIT may change the absorption profile of MPs to leach out chemicals internalized within the particle as well as those bound to the external surface of the particle. Chemicals within MPs often include additives such as flame retardants and bisphenols which are added to plastics to achieve certain properties (Chen, Allgeier, et al., 2019; Gunaalan et al., 2020; Sun, Nan, et al., 2019), while externally bound chemicals may include a variety of pharmaceuticals, fertilizers, pesticides and heavy metals encountered and bound in the freshwater environment (Atugoda et al., 2020; Bradney et al., 2019; Caruso, 2019; Guan et al., 2020). MPs may therefore vector or leach a range of different chemicals into fish and other biota that then produce effects according to factors such as the type of chemical, concentration, where the chemical is released within the GIT and whether the chemicals are taken up across the intestinal barrier (Bradney et al., 2019; Gunaalan et al., 2020).

Microplastics size and shape are also important features affecting the processing of ingested MPs, particularly as small particles, typically $<10 \mu \mathrm{m}$, may translocate across the intestinal barrier, reaching the blood and eventually the rest of the body (Ribeiro et al., 2019). The range of particles that may cross the intestinal barrier does, however, vary with species and only particles of a particular shape, size and chemistry may pass (Ribeiro et al., 2019). The MPs ingested by fish may already be capable of translocation; however, MPs may also be modified and degraded internally throughout the GIT by processes such as maceration, digestion etc. which may produce particles capable of translocation within fish, though this has yet to be investigated.

Within fish, translocated MPs, NPs and their associated contaminants have been recovered from regions such as the liver, muscle and brain (e.g. Abbasi et al., 2018; Batel et al., 2016; Ding et al., 2020; $\mathrm{Su}, \mathrm{Nan}$, et al., 2019), suggesting some risk of MP trophic transfer to piscivorous fauna. The MPs present in a fish at the point of capture should thus be considered a snapshot representing those currently trapped, as well as those yet to be egested or translocated. The varying individual diets, rates of internal physiological processes and time since egestion once caught/euthanized will, therefore, provide varying GIT MP loadings, even if the fish are of the same species, size and sex, and from the same local environment. Additionally, processing tissues of the same fish may provide a greater level of data on fish MP exposure over a slightly longer time period. Tissue MP levels could be correlated to both gut concentrations and factors such as body condition which may depend more on translocated tissue MP concentrations than those accumulated, temporarily or permanently, in the gut. 
Laboratory experiments have demonstrated that goldfish (Carassius auratus, Cyprinidae) may clear $50 \%$ of MPs within $10 \mathrm{hr}$ and $90 \%$ within $33 \mathrm{hr}$ of ingestion (Grigorakis et al., 2017), although egestion rates vary within and between species, depending on the MP and GIT structure, food availability and stomach fullness (Elizalde-Velázquez et al., 2020; Gouin, 2020; Hoang \& Felix-Kim, 2020; Xiong et al., 2019). For example, fibres tend to accumulate at higher levels relative to fragments and pellets, as they are harder to egest (Qiao et al., 2019). Faecal pellets may act as a concentrated source of MPs and organic material which may be utilized by a range of pelagic or benthic organisms as it sinks and settles, transferring MPs and material between biota (Hoang \& Felix-Kim, 2020; Ribeiro et al., 2019).

\section{3 | IMPACTS OF INGESTED MPS ON FRESHWATER FISHES}

Following ingestion, MPs can affect fish via three broad, nonmutually exclusive ways: (a) through physical effects of the MP itself (e.g. blocking the GIT or causing false satiation); (b) the leaching of plasticizers, additives and other harmful chemicals from within the MPs; and (c) by the desorption of harmful pollutants bound to the MPs (Strungaru et al., 2019). The effects of MP exposure on freshwater fish are thus highly variable (Table 2; Figure 2), depending on the interaction of the MP exposure (e.g. concentration, size, polymer and shape) and the ecology of the species. Effects vary from no effect to measurable changes in feeding rates, movement, gene expression, physiology, development, and/or survival (Jovanović, 2017; Wang, Ge, et al., 2019).

In general, much of the experimental MP literature for freshwater fish has focussed on using various life stages of cyprinids (Table 2), especially zebrafish, as the model species to test the effects of MP exposure, most likely due to their extensive use in toxicology research (Dai et al., 2014). The broad diet and different feeding behaviours of zebrafish (Froese \& Pauly, 2019) allow several MP exposure methods, including presented paired with food items (Batel et al., 2018; Lei et al., 2018; Lu et al., 2016), within feed (Mak et al., 2019) and/or via contaminated prey resources (Batel et al., 2016, 2020).

Within controlled experimental studies, freshwater fish MP exposure levels have been highly variable, based on the type, size and shape of MPs, and, taking weight alone, span at least five orders of magnitude from $10 \mu \mathrm{g} / \mathrm{L}$ (Qiao et al., 2019) up to $6 \mathrm{~g} / \mathrm{L}$ (LaPlaca \& van den Hurk, 2020). While these exposure levels are largely within the variation of recorded freshwater environmental loads (e.g. Li, Busquets, et al., 2020; Li et al., 2018; Tibbetts et al., 2018), some higher exposure levels can be considered ecologically irrelevant based on these current freshwater data (e.g. LaPlaca \& van den Hurk, 2020; Mazurais et al., 2015). Several studies have replicated specific environmental MP loadings appropriate to the life stage and habitat of the model fish (e.g. Mazurais et al., 2015; Rochman et al., 2014, 2017), with Naidoo and Glassom (2019) additionally also replicating the types and shapes of MPs in the exposure regime.

Several studies have demonstrated dose-dependent impacts of MP exposure on freshwater fish, though these effects may only occur at a particular MP concentration, suggesting MP thresholds for impact, with the relationship between exposure and impact thus being more complex than a simple linear dose-effect relationship (Lei et al., 2018; Mazurais et al., 2015; Qu et al., 2019; Zhao et al., 2020). MP impacts are often exaggerated when the fish is coexposed to an additional chemical (Banaee et al., 2019; Qiao et al., 2019; Roda et al., 2020), although antagonistic interactions can also occur where MPs modulate the harmful effects of another chemical in the fish, or may also have no interaction at all (Hatami et al., 2019; Oliveira et al., 2013; Wen, Jin, et al., 2018). MP effects may also be life stage-specific, and are occasionally more detrimental to larval than adult fish, especially when MP exposure affects development (Pannetier et al., 2020).

\section{1 | Physiological impacts}

The most common impacts of MP exposure have been recorded at the level of the individual fish, or lower, with impacts most typically including modified patterns of expression and/or protein activity (Figure 2; Table 2). Chemicals within or bound to the MP may also be released within the fish, causing a range of impacts including altered immune activity, expression or blood biochemistry in response to the foreign MP and any associated chemicals (Table 2). GIT oxidative stress and histological damage are common impacts at the organ/tissue level (Figure 2), where the processing of MPs and/or any associated chemicals induce immune response, resulting in localized cell damage and altered morphology of physiological structures (Lu et al., 2016; Yu et al., 2020). Changes in GIT morphology may also alter the types and activity of symbiotic microorganisms, resulting in gut dysbiosis and altered metabolism (Ding et al., 2020; Jabeen et al., 2018; Qiao et al., 2019; Xia et al., 2020; Zhao et al., 2020). Typically, sufficient cellular level effects scale up to tissue/organ then individual-level impacts etc. as different numbers and types of cells are affected by MP exposure (Figure 2).

Blood biochemistry and immune biomarkers may indicate the absorption and translocation of MPs or associated chemicals across the gut, and are useful indicators for identifying dysfunction and damage in various non-GIT organs and tissues (e.g. Banaee et al., 2019; Hamed et al., 2019; Karami et al., 2016; Qiao et al., 2019; Roda et al., 2020). Changes to blood composition may result in anaemia, altered immune function and nutrient supply throughout the body (e.g. Hatami et al., 2019; Karami et al., 2016; Roda et al., 2020). MPs in the brain may interfere with the endocrine or central nervous system, which can impact individual growth, body condition, behaviour and/or survival (e.g. Athey et al., 2020; LaPlaca \& van den Hurk, 2020; Lei et al., 2018; Xia et al., 2020). Functional disruption of key organs, such as the kidneys, liver and brain, can then impact body fluid composition, neurotransmitter and endocrine pathways (Walpitagama et al., 2019; Wang, Wei, et al., 2019), with survival consequences for the individual (Figure 2). 
TABLE 2 Overview of studies accessible before the $15^{\text {th }}$ May 2020 investigating impacts of microplastics on freshwater fish (including estuarine/temporarily freshwater fish), grouped by taxa

\begin{tabular}{|c|c|c|}
\hline Taxa & Impact(s) & Source \\
\hline $\begin{array}{l}\text { Acipenser transmontanus, } \\
\text { Acipenseridae }\end{array}$ & Protein levels and feeding behaviour altered $(\mathrm{J})$ & Rochman et al. $(2017)^{a}$ \\
\hline Ambassis dussumieri, Ambassidae & Growth, survival and body condition reduced $(J)$ & Naidoo and Glassom, (2019) \\
\hline Barbodes gonionotus, Cyprinidae & Increased protein levels; epithelial thickening $(J)$ & Romano et al. (2018) \\
\hline Carassius auratus, Cyprinidae & $\begin{array}{l}\text { Reduced body weight; mouth and GIT damage } \\
\text { GIT damage; oxidative stress; altered growth/activity (L) }\end{array}$ & $\begin{array}{l}\text { Jabeen et al. (2018) } \\
\text { Yang et al. (2020) }\end{array}$ \\
\hline Clarias gariepinus, Clariidae & $\begin{array}{l}\text { GIT damage; protein levels/blood chemistry altered }(\mathrm{J}) \\
\text { Altered protein levels; liver damage; oxidative stress }(\mathrm{J})\end{array}$ & $\begin{array}{l}\text { Karami et al. (2016) } \\
\text { Iheanacho and Odo, (2020) }\end{array}$ \\
\hline Cyprinus carpio, Cyprinidae & $\begin{array}{l}\text { Oxidative stress; protein levels/blood chemistry altered }(\mathrm{J}) \\
\text { Blood chemistry, protein and immune activity altered }(\mathrm{J}) \\
\text { Reduced growth; GIT damage; protein levels altered (L) }\end{array}$ & $\begin{array}{l}\text { Hatami et al. (2019) } \\
\text { Banaee et al. (2019) } \\
\text { Xia et al. (2020) }\end{array}$ \\
\hline Danio rerio, Cyprinidae & $\begin{array}{l}\text { No impact on protein levels or GIT structure (A) } \\
\text { GIT damage; metabolism and protein levels altered (A) } \\
\text { Altered protein levels in adults only (A + E) } \\
\text { GIT damage leading to some mortality (A) } \\
\text { GIT damage; protein levels and gut biota altered (A) } \\
\text { Altered protein levels in larvae only (E + L) } \\
\text { Metabolism, protein levels and gut biota altered (L) } \\
\text { Protein activity and swimming behaviour altered (L) } \\
\text { Altered protein levels (E) } \\
\text { Altered protein levels } \\
\text { GIT damage; protein levels and behaviour altered (A) } \\
\text { GIT damage; protein levels and behaviour altered (A) } \\
\text { GIT damage; metabolism and gut biota altered } \\
\text { Condition, protein levels and metabolism altered (A) } \\
\text { No adverse effects (A) } \\
\text { Oxidative stress; protein levels altered (A) } \\
\text { Protein levels and metabolism altered; delayed hatching (E) } \\
\text { Protein activity altered due to lead leaching (L) }\end{array}$ & $\begin{array}{l}\text { Batel et al. (2016) } \\
\text { Lu et al. (2016) } \\
\text { Batel et al. (2018) } \\
\text { Lei et al. (2018) } \\
\text { Jin et al. (2018) } \\
\text { LeMoine et al. (2018) } \\
\text { Wan et al. (2019) } \\
\text { Qiang and Cheng, (2019) } \\
\text { Cormier et al. (2019) } \\
\text { Qiao et al. (2019) } \\
\text { Limonta et al. (2019) } \\
\text { Mak et al. (2019) } \\
\text { Qiao et al. (2019) } \\
\text { Zhao et al. (2020) } \\
\text { Batel et al. (2020) } \\
\text { Yu et al. (2020) } \\
\text { Duan et al. (2020) } \\
\text { Boyle et al. (2020) }\end{array}$ \\
\hline Dicentrarchus labrax, Moronidae & Protein levels altered and some mortality (L) & Mazurais et al. (2015) \\
\hline Fundulus heteroclitus, Fundulidae & Protein levels altered and some mortality (A) & LaPlaca and van den Hurk (2020) \\
\hline Lates calcarifer, Latidae & Coexposure impaired feeding and swimming $(J)$ & Guven et al. (2018) \\
\hline Menidia beryllina, Atherinopsidae & Reduced growth rate $(\mathrm{L})$ & Athey et al. $(2020)^{a}$ \\
\hline Misgurnus anguillicaudatus, Cobitidae & Coexposure induced oxidative stress (A) & Qu et al. (2019) \\
\hline Oreochromis niloticus, Cichlidae & $\begin{array}{l}\text { Blood and body chemistry altered; anaemia induced }(\mathrm{J}) \\
\text { Altered brain activity and metabolism }(A)\end{array}$ & $\begin{array}{l}\text { Hamed et al. (2019) } \\
\text { Ding et al. (2020) }\end{array}$ \\
\hline Oryzias latipes, Adrianicthyidae & $\begin{array}{l}\text { Protein levels, signalling and germ lines altered }(A) \\
\text { Morphology, behaviour and protein levels altered }(E+L)\end{array}$ & $\begin{array}{l}\text { Rochman et al. (2014) } \\
\text { Pannetier et al. (2020) }\end{array}$ \\
\hline Pimephales promelas, Cyprinidae & $\begin{array}{l}\text { No adverse effects }(\mathrm{L}) \\
\text { Protein levels altered and some mortality (A) }\end{array}$ & $\begin{array}{l}\text { Malinich et al. (2018) } \\
\text { LaPlaca and van den Hurk (2020) }\end{array}$ \\
\hline Pomatoschistus microps, Gobiidae & $\begin{array}{l}\text { Metabolism and neurotransmission altered }(\mathrm{J}) \\
\text { Predatory efficiency and performance reduced }(\mathrm{J}) \\
\text { Protein levels and neurotransmission altered }(\mathrm{J})\end{array}$ & $\begin{array}{l}\text { Oliveira et al. (2013) } \\
\text { de Sá et al. (2015) } \\
\text { Luís et al. }(2015)^{\mathrm{a}}\end{array}$ \\
\hline Prochilodus lineatus, Prochilodontidae & DNA damage; blood, brain and protein activity altered $(\mathrm{J})$ & Roda et al. $(2020)^{a}$ \\
\hline Symphysodon aequifasciatus, Cichlidae & $\begin{array}{l}\text { Predatory behaviour, metabolism and signalling altered }(\mathrm{J}) \\
\text { Oxidative stress; protein levels altered }(\mathrm{J})\end{array}$ & $\begin{array}{l}\text { Wen, Zhang, et al. (2018) } \\
\text { Wen, Jin, et al. (2018) }\end{array}$ \\
\hline
\end{tabular}

Bracketed letters refer to the life stage(s) of taxa: "A," adult; "E," embryo; "J," juvenile; "L," larvae.

andicates studies investigating an interaction between MPs and an additional chemical.

\section{2 | Biological consequences}

Behavioural alterations resulting from MP exposure often occur as MPs and/or their associated chemicals impact cells in the brain or central nervous system which may negatively affect swimming activity and/or survival in freshwater fishes (Limonta et al., 2019; Mak et al., 2019; Qiang \& Cheng, 2019; Yang et al., 2020). Impairments to swimming behaviour might be temporary; however, some studies 


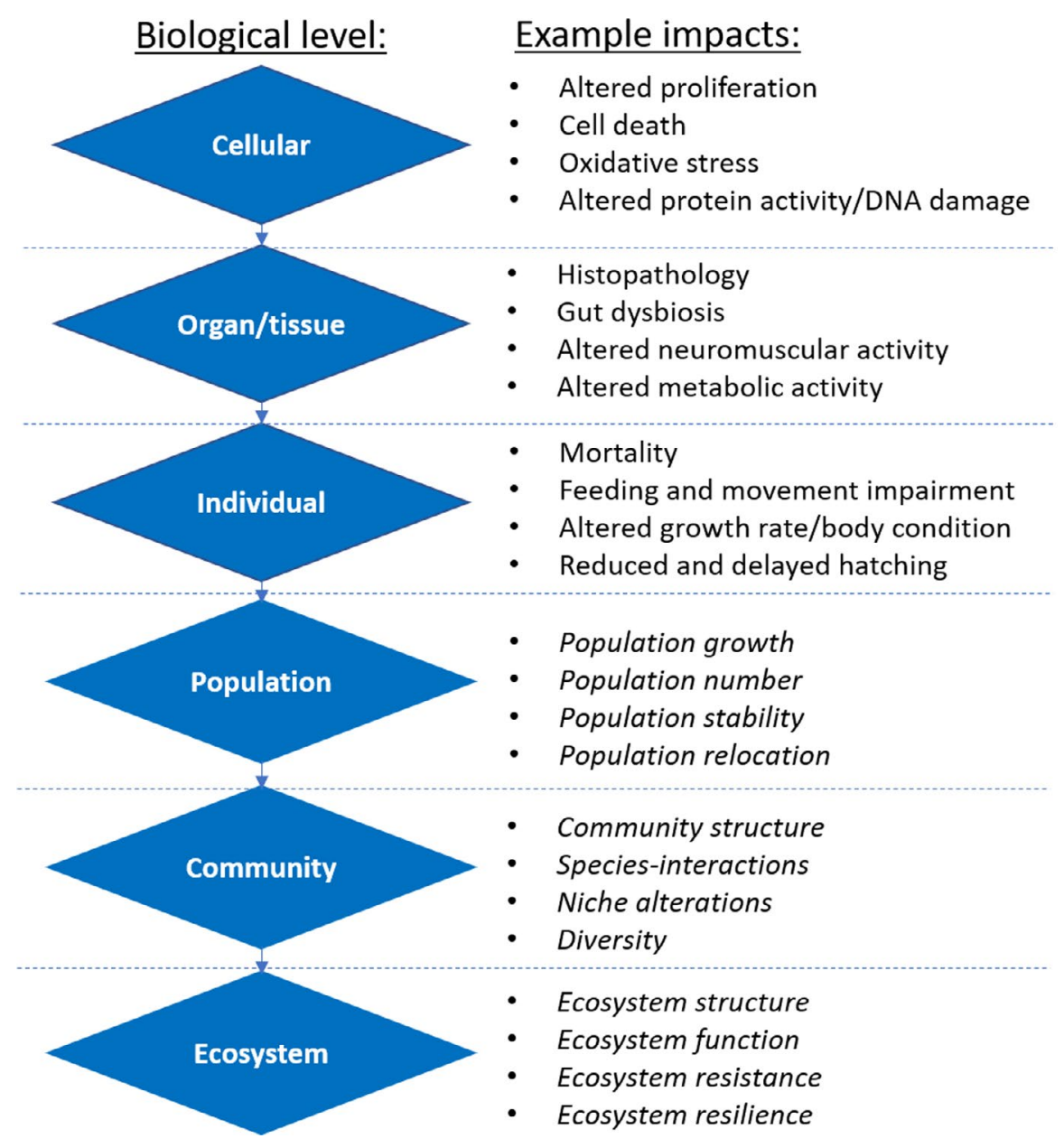

FIGURE 2 Overview of microplastic impacts on freshwater fish at different levels of biological complexity and how impacts can scale up to effects at higher levels of organization. Several common impacts are given for each biological level. Population, community and ecosystem level impacts resulting from freshwater fish exposure are thus far unknown, and so suggested potential impacts are italicized. [Colour figure can be viewed at wileyonlinelibrary.com] also suggest more damaging effects if MP exposure impacts early development (Duan et al., 2020; Pannetier et al., 2020). Fish eggs can also externally bind MPs and/or uptake smaller NPs that can alter gaseous exchange and delay hatching times (Batel et al., 2018; Duan et al., 2020).

MP-induced reductions in predatory behaviour and efficiency have been demonstrated in juvenile common goby (Pomatoschistus microps, Gobiidae), most likely through affecting the discrimination of copresented prey and MP items (de Sá et al., 2015). Changes to predator-prey dynamics may modify food webs and communities through altering interaction strengths (Figure 2) and is particularly relevant since higher trophic levels and predators appear to be more vulnerable to MPs than their prey (Huang, Lin, et al., 2020). While goldfish experimentally rejected MPs that could not be chewed and swallowed, this processing damaged the mouth (Jabeen et al., 2018), potentially affecting their subsequent foraging behaviours and consumption rates.

\section{3 | MPs as biological vectors}

Microplastics are often implicated to aid in the binding and transport of various pathogens and invasive species (Caruso, 2019; Shen et al., 2019); however, the potential role of MPs in macroparasite transport remains unexplored. As MP uptake in fish occurs predominately through feeding (Gouin, 2020; Ribeiro et al., 2019), then the association of parasites to MPs may potentially benefit trophically transmitted parasites through increasing their transmission probabilities to fish hosts. MPs might also indirectly increase transmission rates and parasite virulence by suppressing the immune response and/or the general condition of the impacted individual (Limonta et al., 2019; Luís et al., 2015). The trophic transmission of parasites can often involve parasite manipulation of the behaviour of the intermediate host to promote their ingestion by a final host (Thomas et al., 2010). For example, infection of three-spined stickleback (Gasterosteus aculeatus, Gasterosteidae) by the cestode Schistocephalus solidus (Schistocephalidae) results in infected fish foraging on smaller prey items (Barber \& Huntingford, 1995) and altering habitat utilization to increase predation encounter and subsequent parasite transfer to a final bird host (Barber et al., 2004). These parasite-mediated behavioural modifications can result in trophic differences between infected and uninfected fish within populations (Britton \& Andreou, 2016), potentially also altering their exposure to MPs.

Nevertheless, the consequences of MPs for freshwater fish hostparasite relationships remain uncertain. In marine environments, anecdotal evidence suggests that MPs and parasites accumulate in the same part of the gut in seals (Hernandez-Milian et al., 2019), and fish closer to urban areas have both higher MP and parasite loads (Alves 
et al., 2016). Microplastics and trophic (ingested) parasites are also most likely accumulated in the same way, with typically more of both in larger and/or predatory individuals (Lester \& McVinish, 2016). Several exposure studies in freshwater fish have also suggested that MP exposure might increase susceptibility to parasites or disease (Limonta et al., 2019; Luís et al., 2015), though this was not studied. In addition, environmental plastics do attract and harbour distinct bacterial and fungal assemblages compared to natural particles, many of which can be pathogenic to fish, and may provide similar mechanisms for transporting parasites (Gong et al., 2019; Munier \& Bendell, 2018; Vethaak \& Leslie, 2016).

\section{4 | FUTURE PERSPECTIVES}

\section{1 | Experimental approaches}

Microplastics exposure studies have revealed a wide range of effects in freshwater fishes (Table 2), but there remains considerable uncertainty in how these translate into measurable impacts in wild populations, particularly above the individual level (Figure 2). Understanding the impacts of MPs on freshwater fish requires, at least in part, controlled studies that enable the decoupling of the impacts of MPs from other stressors and that use appropriate exposure conditions and model species. Therefore, it is recommended that exposure studies initially test the effects of current (or predicted) ecologically relevant MP concentrations and ensure that the concentrations, sizes, shapes and polymers of the MPs reflect the natural exposure levels of that species and life stage. In controlled studies to date, there has been a bias towards using spherical beads during exposure (e.g. Mazurais et al., 2015; Oliveira et al., 2013; de Sá et al., 2015), so there is also a need to further investigate the impacts on freshwater fish arising from exposure to fragments, fibres and films, especially as these are already known to have different egestion rates in freshwater fish (Qiao et al., 2019). The actual exposure mechanism should also aim to simulate how a particular fish might encounter MPs in the wild, such as sprinkling floating MPs and food for surface filter feeders, but spiking resource items with MPs for species at higher trophic levels.

Most studies have exposed fish to MPs via the water when feeding (e.g. Batel et al., 2018; Lei et al., 2018; Lu et al., 2016), with this an appropriate exposure route for most of the investigated species and life stages to date, typically larvae/juveniles of cyprinid zooplanktivores. However, there have been fewer impact studies using benthic-feeding or piscivorous fishes (e.g. Iheanacho \& Odo, 2020; Karami et al., 2016; Oliveira et al., 2013; de Sá et al., 2015), as well as a lack of studies exposing fish via contaminated resources (e.g. Batel et al., 2016, 2020; Rochman et al., 2017), despite this often being a more effective MP transmission route than coupled with commercial fish food (Athey et al., 2020). Consequently, there remains a lack of knowledge over whether benthic fishes, which often tend to ingest more MPs than pelagic feeders within the same environment (McGoran et al., 2017, 2018; McNeish et al., 2018), are similarly disproportionally impacted by MP exposure. Trophic transfer studies could additionally determine if MP transfer efficiencies are similar from prey to predatory fish as between invertebrates and fish, which might explain different MP ingestion patterns in wild fish occupying different niches and trophic levels (Campbell et al., 2017; Hurt et al., 2020; McNeish et al., 2018; Roch et al., 2019).

For scaling up from individual MP impacts to higher levels of biological organization (Figure 2), the controlled conditions provided within mesocosm studies provide a strong experimental framework using fully factorial designs that enable the effects of MPs on community structure and function to be quantified. Such studies enable complexity to be developed and investigated, including how MP impacts are affected by other stressors, such as warming and nutrient enrichment. For example, studies utilizing mesocosms have experimentally demonstrated the trophic transfer of NPs across several trophic levels into top-predator fish (Chae et al., 2018; Mattsson et al., 2015), where quantified impacts included histological damage and alterations to feeding, shoaling behaviours and metabolism.

Alternative experimental approaches, such as exposure studies translocating organisms within mesh cages, also provide opportunities to identify how different species respond to different MP levels in the environment, as well as whether previous exposure to MPs may impact susceptibility to future exposure. Similar studies have already been completed in marine systems for blue mussel (Mytilus edulis, Mytilidae) (Kazour \& Amara, 2020) and European flounder (Platicthys flesus, Pleuronectidae) (Kazour et al., 2018) and are another promising experimental framework for future MP research in freshwater fishes.

\section{2 | Nonfatal field sampling}

Current field sampling methods tend to result in fish being euthanized for analyses in the laboratory that provide limited short-term data (Ferreira et al., 2016; Possatto et al., 2011). Correspondingly, future studies should consider using nondestructive sampling methods where feasible. For example, stomach flushing has been used to recover up to $95 \%$ of spiked MP samples from juvenile Mexican crocodiles (Crocodylus moreletii, Crocodilidae) (Gonzalez-Jauregui et al., 2019), with flushing techniques already used in fish dietary analyses (e.g. Correa \& Anderson, 2016; Kamler \& Pope, 2001). It should, however, be noted that stomach lavage is only suitable for larger fish and can potentially cause damage, and sometimes fatality, in smaller and/or agastric individuals. The application of nonfatal MP recovery techniques can then be complemented by the ecological application of stable isotope analysis (SIA) that can provide temporal and spatial information on fish diet composition (Grey, 2006). While SIA would be unable to quantify MP loads in individual fish, it does enable information to be developed for populations in relation to their trophic (isotopic) niches (Jackson et al., 2012) and the extent of individual dietary specialization (Araújo et al., 2011), that can be tested against the numbers of MPs recovered from the GIT. This complementary approach could also identify whether differences in MP loads between individuals are a consequence or driver of dietary 
specialization (Britton \& Andreou, 2016). For MPs encountered passively, such as those on the gills (Hurt et al., 2020) and epidermis (Abbasi et al., 2018), then the use of "skin scrapes" and "gill swabs" (e.g. Roberts et al., 2009; Young et al., 2008) could prove suitable and noninvasive methods to quantify this mechanism of MP uptake.

Research investigating the bioaccumulation of MPs has so far focused almost exclusively on those found in the GIT (Gouin, 2020), despite being continuous with the external environment and smaller MPs being known to translocate to other parts of the body (Ribeiro et al., 2019), including the liver, muscle and brain of freshwater fish (e.g. Abbasi et al., 2018; Batel et al., 2016; Ding et al., 2020; Su, Nan, et al., 2019). The development of nondestructive techniques for tracing MPs in fish organs can potentially utilize MP carbon isotopes, as these have been used experimentally to demonstrate the incorporation of MP materials by microbes and to track the trophic transfer of these particles into animals (Taipale et al., 2019), as fluorescent dyes are often problematic and less reliable (Schür et al., 2019).

\section{3 | Laboratory analyses}

Reviews of current laboratory processing techniques highlight a range of different methods of digestion and MP analyses (Collard et al., 2019), with particular techniques working better for different species (Bianchi et al., 2020), but that might under- or over-estimate counts for particular polymers (Karami et al., 2017). A single, standardized procedure for all MP processing is, therefore, not possible, although attempts should be made to reduce the signal-noise ratio in samples and to comprehensively outline and critique the processing steps. In a review of plastic ingestion in wild freshwater fish, Collard et al. (2019) made numerous recommendations to standardize fish MP processing protocols, including on sample sizes, MP target size and visualization methods. In addition to these recommendations, where additional density separation of samples is employed, floatation reagents should have a minimum relative density of $1.5 \mathrm{~g} \mathrm{~cm}^{-3}$ to maximize the number of MPs recovered from samples and to reduce systematic underrepresentation of denser plastics (Coppock et al., 2017; Quinn et al., 2017).

Contamination is a recurring problem in MP research and it is important that all reasonable attempts are made to eliminate contamination and to determine the efficacy of implemented contamination control steps by quantifying remaining sources of contamination. Best practice reviews suggest the wearing of nonplastic personal protection equipment, the use of laminar flow cabinets to minimize atmospheric sample exposure, carrying out procedural blanks, and ensuring reagents and equipment are filtered and cleaned prior to use are all effective ways to reduce contamination to acceptable levels (e.g. <10\% of sample counts) (e.g. Collard et al., 2019; Dehaut et al., 2019; Gong \& Xie, 2020; Lusher et al., 2017; Scopetani et al., 2020). Studies should additionally outline the steps taken to reduce contamination, as well as declare any residual contamination and/or subsequent data correction.
Microplastic visual screening varies with individual experience and the particular shapes, sizes and colours of MP particles (Cadiou et al., 2020). MP screenings under microscopy should aim to be conservative and carried out blind, in a randomized order, with a pre-determined and standardized search time and search criteria to reduce bias and variation in counts. The processing of samples by multiple observers is another effective way of reducing individual bias by assessing interobserver reliability.

Visual screening should also be supplemented by chemical confirmation, through spectroscopy or other techniques, on a subset of samples (e.g. 10\%) to confirm the proportion of suspected MPs that are actually plastics and to determine polymer types. Automated techniques, such as image processing software, should also be favoured preferentially to more subjective manual visual processing (Andrade et al., 2020; Dehaut et al., 2019; Renner et al., 2019). Many studies on MPs in freshwater fish have not utilized chemical techniques, indicated by those studies in Table 1 without polymer data, and so for these studies estimates of MP incidence are likely to be unreliable and to include various other particles of nonplastic origin. As an example, Collard et al., (2018) identified approximately a quarter of anthropogenic particles as plastics while Slootmaekers et al., (2019) found only half of suspected MPs were actually plastic. The chemical analysis of suspected MPs is therefore critical to determine reliable MP counts and to assess the actual risks of MP pollution faced by freshwater fish.

\subsection{Scaling up complexity}

Much MP research in freshwater fish has been on single species (Table 1) and has focussed on individual-level effects and below (Table 2; Figure 2). Consequently, as knowledge develops, there is a need to fill in the gaps to understand MP impacts at population, community and ecosystem levels (Figure 2), as well as continuing to investigate the relative impacts of body size, sex, trophic level and other traits that affect MP ingestion patterns. Field studies should aim to collect representative communities with sufficient numbers of fish per trophic level and functional group (excluding those of conservation concern), with consideration of sampling across different seasons and under different river flows and levels.

\section{5 | CONCLUSIONS}

Both field and laboratory approaches have, to date, contributed knowledge on how particular characteristics of freshwater fish affect the encounter, ingestion, effects and egestion of MPs. Studies highlight considerable variability in ingestion patterns and effects, but that these differences can generally be explained through a combination of traits of the fish (e.g. size, trophic level, habitat), its environment (e.g. the extent of local urbanization) and the MP characteristics (e.g. size, shape, polymer, internal/external chemicals). Future field research should identify MPs in novel fish species and 
locations, and develop population level and community-wide assessment approaches using standardized methods that maximize MP recovery while minimizing contamination. Experimental studies should ensure that exposure regimes and routes are environmentally relevant and investigate uptake and effects in a wider range of species, including piscivorous and benthic fishes. The interactive impacts of MPs with other anthropogenic stressors are also required, given that MP pollution is likely acting as a further stressor in environments already exposed to multiple stressors. Data generated through fieldand laboratory-based studies can then move towards a more quantitative assessment of the risks faced by particular freshwater fish, with criteria on freshwater MPs able to be incorporated into freshwater monitoring programmes and species action plans.

\section{ACKNOWLEDGEMENT}

The review was funded by the Fisheries Society of the British Isles through a studentship awarded to BP. We are grateful to two anonymous reviewers whose comments dramatically improved the quality of the manuscript.

\section{DATA AVAILABILITY STATEMENT}

Data availability is not applicable to this article as no new data were created or analysed in this study.

\section{ORCID}

Ben Parker iD https://orcid.org/0000-0001-6731-7852

Demetra Andreou (iD https://orcid.org/0000-0001-9242-4692

lain D. Green (iD https://orcid.org/0000-0002-0418-3524

J. Robert Britton iD https://orcid.org/0000-0003-1853-3086

\section{REFERENCES}

Abbasi, S., Soltani, N., Keshavarzi, B., Moore, F., Turner, A., \& Hassanaghaei, M. (2018). Microplastics in different tissues of fish and prawn from the Musa Estuary, Persian Gulf. Chemosphere, 205, 80-87. https://doi.org/10.1016/j.chemosphere.2018.04.076

Akdogan, Z., \& Guven, B. (2019). Microplastics in the environment: A critical review of current understanding and identification of future research needs. Environmental Pollution, 254, 113011. https://doi. org/10.1016/j.envpol.2019.113011

Alves, V. E. N., Patrício, J., Dolbeth, M., Pessanha, A., Palma, A. R. T., Dantas, E. W., \& Vendel, A. L. (2016). Do different degrees of human activity affect the diet of Brazilian silverside Atherinella brasiliensis? Journal of Fish Biology, 89, 1239-1257. https://doi.org/10.1111/ jfb.13023

Anbumani, S., \& Kakkar, P. (2018). Ecotoxicological effects of microplastics on biota: A review. Environmental Science and Pollution Research, 25, 14373-14396. https://doi.org/10.1007/s11356-018-1999-x

Andrade, J. M., Ferreiro, B., López-Mahía, P., \& Muniategui-Lorenzo, S. (2020). Standardization of the minimum information for publication of infrared-related data when microplastics are characterized. Marine Pollution Bulletin, 154, 111035. https://doi.org/10.1016/j. marpolbul.2020.111035

Andrade, M. C., Winemiller, K. O., Barbosa, P. S., Fortunati, A., Chelazzi, D., Cincinelli, A., \& Giarrizzo, T. (2019). First account of plastic pollution impacting freshwater fishes in the Amazon: Ingestion of plastic debris by piranhas and other serrasalmids with diverse feeding habits. Environmental Pollution, 244, 766-773. https://doi.org/10.1016/j. envpol.2018.10.088
Andrady, A. L. (2011). Microplastics in the marine environment. Marine Pollution Bulletin, 62, 1596-1605. https://doi.org/10.1016/j.marpo Ibul.2011.05.030

Andrady, A. L., \& Neal, M. A. (2009). Applications and societal benefits of plastics. Philosophical Transactions of the Royal Society B: Biological Sciences, 364, 1977-1984. https://doi.org/10.1098/rstb.2008.0304

Araújo, M. S., Bolnick, D. I., \& Layman, C. A. (2011). The ecological causes of individual specialisation. Ecology Letters, 14, 948-958. https://doi. org/10.1111/j.1461-0248.2011.01662.x

Athey, S. N., Albotra, S. D., Gordon, C. A., Monteleone, B., Seaton, P., Andrady, A. L., Taylor, A. R., \& Brander, S. M. (2020). Trophic transfer of microplastics in an estuarine food chain and the effects of a sorbed legacy pollutant. Limnology and Oceanography Letters, 5, 154162. https://doi.org/10.1002/lol2.10130

Atugoda, T., Wijesekara, H., Werellagama, D. R. I. B., Jinadasa, K. B. S. N., Bolan, N. S., \& Vithanage, M. (2020). Adsorptive interaction of antibiotic ciprofloxacin on polyethylene microplastics: Implications for vector transport in water. Environmental Technology \& Innovation, 19, 100971. https://doi.org/10.1016/j.eti.2020.100971

Banaee, M., Soltanian, S., Sureda, A., Gholamhosseini, A., Haghi, B. N., Akhlaghi, M., \& Derikvandy, A. (2019). Evaluation of single and combined effects of cadmium and micro-plastic particles on biochemical and immunological parameters of common carp (Cyprinus carpio). Chemosphere, 236, 124335. https://doi.org/10.1016/j.chemo sphere.2019.07.066

Bank, M. S., \& Hansson, S. V. (2019). The plastic cycle: A novel and holistic paradigm for the Anthropocene. Environmental Science and Technology, 53, 7177-7179. https://doi.org/10.1021/acs.est.9b02942

Barber, I., \& Huntingford, F. A. (1995). The effect of Schistocephalus solidus (Cestoda: Pseudophyllidea) on the foraging and shoaling behaviour of three-spined sticklebacks, Gasterosteus aculeatus. Behaviour, 132, 1223-1240. https://doi.org/10.1163/156853995X00540

Barber, I., Svensson, P., \& Walker, P. (2004). Behavioural responses to simulated avian predation in female three spined sticklebacks: The effect of experimental Schistocephalus solidus infections. Behaviour, $141,1425-1440$

Barnes, D. K. A., Galgani, F., Thompson, R. C., \& Barlaz, M. (2009). Accumulation and fragmentation of plastic debris in global environments. Philosophical Transactions of the Royal Society B: Biological Sciences, 364, 1985-1998. https://doi.org/10.1098/rstb.2008.0205

Batel, A., Baumann, L., Carteny, C. C., Cormier, B., Keiter, S. H., \& Braunbeck, T. (2020). Histological, enzymatic and chemical analyses of the potential effects of differently sized microplastic particles upon long-term ingestion in zebrafish (Danio rerio). Marine Pollution Bulletin, 153,111022. https://doi.org/10.1016/j.marpo Ibul.2020.111022

Batel, A., Borchert, F., Reinwald, H., Erdinger, L., \& Braunbeck, T. (2018). Microplastic accumulation patterns and transfer of benzo[a] pyrene to adult zebrafish (Danio rerio) gills and zebrafish embryos. Environmental Pollution, 235, 918-930. https://doi.org/10.1016/j. envpol.2018.01.028

Batel, A., Linti, F., Scherer, M., Erdinger, L., \& Braunbeck, T. (2016). Transfer of benzo[a]pyrene from microplastics to Artemia nauplii and further to zebrafish via a trophic food web experiment: CYP1A induction and visual tracking of persistent organic pollutants. Environmental Toxicology and Chemistry, 35, 1656-1666. https://doi. org/10.1002/etc.3361

Belzagui, F., Crespi, M., Álvarez, A., Gutiérrez-Bouzán, C., \& Vilaseca, M. (2019). Microplastics' emissions: Microfibers' detachment from textile garments. Environmental Pollution, 248, 1028-1035. https://doi. org/10.1016/j.envpol.2019.02.059

Bessa, F., Barría, P., Neto, J. M., Frias, J. P. G. L., Otero, V., Sobral, P., \& Marques, J. C. (2018). Occurrence of microplastics in commercial fish from a natural estuarine environment. Marine Pollution Bulletin, 128, 575-584. https://doi.org/10.1016/j.marpolbul.2018.01.044 
Bianchi, J., Valente, T., Scacco, U., Cimmaruta, R., Sbrana, A., Silvestri, C., \& Matiddi, M. (2020). Food preference determines the best suitable digestion protocol for analysing microplastic ingestion by fish. Marine Pollution Bulletin, 154, 111050. https://doi.org/10.1016/j. marpolbul.2020.111050

Biginagwa, F. J., Mayoma, B. S., Shashoua, Y., Syberg, K., \& Khan, F. R. (2016). First evidence of microplastics in the African Great Lakes: Recovery from Lake Victoria Nile perch and Nile tilapia. Journal of Great Lakes Research, 42, 146-149. https://doi.org/10.1016/j. jglr.2015.10.012

Blettler, M. C. M., Garello, N., Ginon, L., Abrial, E., Espinola, L. A., \& Wantzen, K. M. (2019). Massive plastic pollution in a mega-river of a developing country: Sediment deposition and ingestion by fish (Prochilodus lineatus). Environmental Pollution, 255, 113348. https:// doi.org/10.1016/j.envpol.2019.113348

Bondelind, M., Sokolova, E., Nguyen, A., Karlsson, D., Karlsson, A., \& Björklund, K. (2020). Hydrodynamic modelling of traffic-related microplastics discharged with stormwater into the Göta River in Sweden. Environmental Science and Pollution Research, 27, 1-13. https://doi.org/10.1007/s11356-020-08637-z

Boucher, J., Faure, F., Pompini, O., Plummer, Z., Wieser, O., \& Felippe de Alencastro, L. (2019). (Micro) plastic fluxes and stocks in Lake Geneva basin. TrAC - Trends in Analytical Chemistry, 112, 66-74. https://doi. org/10.1016/j.trac.2018.11.037

Boyle, D., Catarino, A. I., Clark, N. J., \& Henry, T. B. (2020). Polyvinyl chloride (PVC) plastic fragments release $\mathrm{Pb}$ additives that are bioavailable in zebrafish. Environmental Pollution, 263, 114422. https:// doi.org/10.1016/j.envpol.2020.114422

Bradney, L., Wijesekara, H., Palansooriya, K. N., Obadamudalige, N., Bolan, N. S., Ok, Y. S., Rinklebe, J., Kim, K.-H., \& Kirkham, M. B. (2019). Particulate plastics as a vector for toxic trace-element uptake by aquatic and terrestrial organisms and human health risk. Environment International, 131, 104937. https://doi.org/10.1016/j. envint.2019.104937

Britton, J. R., \& Andreou, D. (2016). Parasitism as a driver of trophic niche specialisation. Trends in Parasitology, 32, 437-445. https://doi. org/10.1016/j.pt.2016.02.007

Cadiou, J.-F., Gerigny, O., Koren, Š., Zeri, C., Kaberi, H., Alomar, C., Panti, C., Fossi, M. C., Adamopoulou, A., Digka, N., Deudero, S., Concato, M., Carbonell, A., Baini, M., Galli, M., \& Galgani, F. (2020). Lessons learned from an intercalibration exercise on the quantification and characterisation of microplastic particles in sediment and water samples. Marine Pollution Bulletin, 154, 111097. https://doi.org/10.1016/j. marpolbul.2020.111097

Cai, Y., Yang, T., Mitrano, D. M., Heuberger, M., Hufenus, R., \& Nowack, B. (2020). Systematic study of microplastic fiber release from 12 different polyester textiles during washing. Environmental Science \& Technology, 54, 4847-4855. https://doi.org/10.1021/acs. est.9b07395

Campanale, C., Stock, F., Massarelli, C., Kochleus, C., Bagnuolo, G., Reifferscheid, G., \& Uricchio, V. F. (2019). Microplastics and their possible sources: The example of Ofanto river in southeast Italy. Environmental Pollution, 258, 113284. https://doi.org/10.1016/j. envpol.2019.113284

Campbell, S. H., Williamson, P. R., \& Hall, B. D. (2017). Microplastics in the gastrointestinal tracts of fish and the water from an urban prairie creek. FACETS, 2, 395-409. https://doi.org/10.1139/facet s-2017-0008

Carpenter, E. J., Anderson, S. J., Harvey, G. R., Miklas, H. P., \& Peck, B. B. (1972). Polystyrene spherules in coastal waters. Science, 178, 749750. https://doi.org/10.1126/science.178.4062.749

Carpenter, E. J., \& Smith, K. L. (1972). Plastics on the Sargasso sea surface. Science, 175, 1240-1241. https://doi.org/10.1126/scien ce. 175.4027 .1240
Caruso, G. (2019). Microplastics as vectors of contaminants. Marine Pollution Bulletin, 146, 921-924. https://doi.org/10.1016/j.marpo Ibul.2019.07.052

Casabianca, S., Capellacci, S., Penna, A., Cangiotti, M., Fattori, A., Corsi, I., Ottaviani, M. F., \& Carloni, R. (2019). Physical interactions between marine phytoplankton and PET plastics in seawater. Chemosphere, 238, 124560. https://doi.org/10.1016/j.chemo sphere.2019.124560

Chae, Y., Kim, D., Kim, S. W., \& An, Y. J. (2018). Trophic transfer and individual impact of nano-sized polystyrene in a four-species freshwater food chain. Scientific Reports, 8, 1-11. https://doi.org/10.1038/s4159 8-017-18849-y

Chen, G., Feng, Q., \& Wang, J. (2020). Mini-review of microplastics in the atmosphere and their risks to humans. Science of the Total Environment, 703, 135504. https://doi.org/10.1016/j.scitotenv.2019.135504

Chen, Q., Allgeier, A., Yin, D., \& Hollert, H. (2019). Leaching of endocrine disrupting chemicals from marine microplastics and mesoplastics under common life stress conditions. Environment International, 130, 104938. https://doi.org/10.1016/j.envint.2019.104938

Chen, X., Xiong, X., Jiang, X., Shi, H., \& Wu, C. (2019). Sinking of floating plastic debris caused by biofilm development in a freshwater lake. Chemosphere, 222, 856-864. https://doi.org/10.1016/j.chemo sphere.2019.02.015

Cheung, L., Lui, C., \& Fok, L. (2018). Microplastic contamination of wild and captive flathead grey mullet (Mugil cephalus). International Journal of Environmental Research and Public Health, 15, 597. https://doi. org/10.3390/ijerph15040597

Coffin, S., Lee, I., Gan, J., \& Schlenk, D. (2019). Simulated digestion of polystyrene foam enhances desorption of diethylhexyl phthalate (DEHP) and in vitro estrogenic activity in a size-dependent manner. Environmental Pollution, 246, 452-462. https://doi.org/10.1016/j. envpol.2018.12.011

Collard, F., Gasperi, J., Gabrielsen, G. W., \& Tassin, B. (2019). Plastic particle ingestion by wild freshwater fish: A critical review. Environmental Science and Technology, 53, 12974-12988. https://doi.org/10.1021/ acs.est.9b03083

Collard, F., Gasperi, J., Gilbert, B., Eppe, G., Azimi, S., Rocher, V., \& Tassin, B. (2018). Anthropogenic particles in the stomach contents and liver of the freshwater fish Squalius cephalus. Science of the Total Environment, 643, 1257-1264. https://doi.org/10.1016/j.scito tenv.2018.06.313

Collard, F., Gilbert, B., Eppe, G., Roos, L., Compère, P., Das, K., \& Parmentier, E. (2017). Morphology of the filtration apparatus of three planktivorous fishes and relation with ingested anthropogenic particles. Marine Pollution Bulletin, 116, 182-191. https://doi. org/10.1016/j.marpolbul.2016.12.067

Collicutt, B., Juanes, F., \& Dudas, S. E. (2019). Microplastics in juvenile Chinook salmon and their nearshore environments on the east coast of Vancouver Island. Environmental Pollution, 244, 135-142. https:// doi.org/10.1016/j.envpol.2018.09.137

Conley, K., Clum, A., Deepe, J., Lane, H., \& Beckingham, B. (2019). Wastewater treatment plants as a source of microplastics to an urban estuary: Removal efficiencies and loading per capita over one year. Water Research X, 3,100030. https://doi.org/10.1016/j. wroa.2019.100030

Coppock, R. L., Cole, M., Lindeque, P. K., Queirós, A. M., \& Galloway, T. S. (2017). A small-scale, portable method for extracting microplastics from marine sediments. Environmental Pollution, 230, 829-837. https://doi.org/10.1016/j.envpol.2017.07.017

Cormier, B., Batel, A., Cachot, J., Bégout, M. L., Braunbeck, T., Cousin, X., \& Keiter, S. H. (2019). Multi-laboratory hazard assessment of contaminated microplastic particles by means of enhanced fish embryo test with the zebrafish (Danio rerio). Frontiers in Environmental Science, 7, 1-14. https://doi.org/10.3389/fenvs.2019.00135 
Correa, S. B., \& Anderson, J. T. (2016). A non-destructive sampling protocol for field studies of seed dispersal by fishes. Journal of Fish Biology, 88, 1989-2003. https://doi.org/10.1111/jfb.12963

Dai, Y.-J., Jia, Y.-F., Chen, N. A., Bian, W.-P., Li, Q.-K., Ma, Y.-B., Chen, Y.-L., \& Pei, D.-S. (2014). Zebrafish as a model system to study toxicology. Environmental Toxicology and Chemistry, 33, 11-17. https:// doi.org/10.1002/etc.2406

Daily, J., \& Hoffman, M. J. (2020). Modeling the three-dimensional transport and distribution of multiple microplastic polymer types in Lake Erie. Marine Pollution Bulletin, 154, 111024. https://doi.org/10.1016/j. marpolbul.2020.111024

Dantas, D. V., Barletta, M., \& da Costa, M. F. (2012). The seasonal and spatial patterns of ingestion of polyfilament nylon fragments by estuarine drums (Sciaenidae). Environmental Science and Pollution Research, 19, 600-606. https://doi.org/10.1007/s1135 6-011-0579-0

De Falco, F., Di Pace, E., Cocca, M., \& Avella, M. (2019). The contribution of washing processes of synthetic clothes to microplastic pollution. Scientific Reports, 9, 6633. https://doi.org/10.1038/s41598-01943023-x

de Sá, L. C., Luís, L. G., \& Guilhermino, L. (2015). Effects of microplastics on juveniles of the common goby (Pomatoschistus microps): Confusion with prey, reduction of the predatory performance and efficiency, and possible influence of developmental conditions. Environmental Pollution, 196, 359-362. https://doi.org/10.1016/j. envpol.2014.10.026

de Souza Machado, A. A., Kloas, W., Zarfl, C., Hempel, S., \& Rillig, M. C. (2018). Microplastics as an emerging threat to terrestrial ecosystems. Global Change Biology, 24, 1405-1416. https://doi.org/10.1111/ gcb.14020

de Villiers, S. (2019). Microfibre pollution hotspots in river sediments adjacent to South Africa's coastline. Water SA, 45, 97. https://doi. org/10.4314/wsa.v45i1.11

Dehaut, A., Hermabessiere, L., \& Duflos, G. (2019). Current frontiers and recommendations for the study of microplastics in seafood. TrAC - Trends in Analytical Chemistry, 116, 346-359. https://doi. org/10.1016/j.trac.2018.11.011

Ding, J., Huang, Y., Liu, S., Zhang, S., Zou, H., Wang, Z., Zhu, W., \& Geng, J. (2020). Toxicological effects of nano- and micro-polystyrene plastics on red tilapia: Are larger plastic particles more harmless? Journal of Hazardous Materials, 396, 122693. https://doi.org/10.1016/j.jhazm at.2020.122693

Dodds, W. K., Perkin, J. S., \& Gerken, J. E. (2013). Human impact on freshwater ecosystem services: A global perspective. Environmental Science and Technology, 47, 9061-9068. https://doi.org/10.1021/ es4021052

Duan, Z., Duan, X., Zhao, S., Wang, X., Wang, J., Liu, Y., Peng, Y., Gong, Z., \& Wang, L. (2020). Barrier function of zebrafish embryonic chorions against microplastics and nanoplastics and its impact on embryo development. Journal of Hazardous Materials, 395, 122621. https://doi. org/10.1016/j.jhazmat.2020.122621

Edo, C., González-Pleiter, M., Leganés, F., Fernández-Piñas, F., \& Rosal, R. (2020). Fate of microplastics in wastewater treatment plants and their environmental dispersion with effluent and sludge. Environmental Pollution, 259, 113837. https://doi.org/10.1016/j. envpol.2019.113837

Elizalde-Velázquez, A., Carcano, A. M., Crago, J., Green, M. J., Shah, S. A., \& Cañas-Carrell, J. E. (2020). Translocation, trophic transfer, accumulation and depuration of polystyrene microplastics in Daphnia magna and Pimephales promelas. Environmental Pollution, 259, 113937. https://doi.org/10.1016/j.envpol.2020.113937

Enfrin, M., Dumée, L. F., \& Lee, J. (2019). Nano/microplastics in water and wastewater treatment processes - Origin, impact and potential solutions. Water Research, 161, 621-638. https://doi.org/10.1016/j. watres.2019.06.049
Eo, S., Hong, S. H., Song, Y. K., Han, G. M., \& Shim, W. J. (2019). Spatiotemporal distribution and annual load of microplastics in the Nakdong River, South Korea. Water Research, 160, 228-237. https:// doi.org/10.1016/j.watres.2019.05.053

Fadare, O. O., Wan, B., Zhao, L., \& Guo, L.-H. (2020). Microplastics from consumer plastic food containers: Are we consuming it? Chemosphere, 253. 126787. https://doi.org/10.1016/j.chemosphere.2020.126787

Faure, F., Demars, C., Wieser, O., Kunz, M., \& de Alencastro, L. F. (2015). Plastic pollution in Swiss surface waters: Nature and concentrations, interaction with pollutants. Environmental Chemistry, 12, 582-591. https://doi.org/10.1071/EN14218

Feng, Z., Zhang, T., Shi, H., Gao, K., Huang, W., Xu, J., Wang, J., Wang, R., Li, J. I., \& Gao, G. (2020). Microplastics in bloom-forming macroalgae: Distribution, characteristics and impacts. Journal of Hazardous Materials, 397, 122752. https://doi.org/10.1016/j.jhazm at.2020.122752

Ferreira, G. V. B., Barletta, M., \& Lima, A. R. A. (2019). Use of estuarine resources by top predator fishes. How do ecological patterns affect rates of contamination by microplastics? Science of the Total Environment, 655, 292-304. https://doi.org/10.1016/j.scito tenv.2018.11.229

Ferreira, G. V. B., Barletta, M., Lima, A. R. A., Dantas, D. V., Justino, A. K. S., \& Costa, M. F. (2016). Plastic debris contamination in the life cycle of Acoupa weakfish (Cynoscion acoupa) in a tropical estuary. ICES Journal of Marine Science, 73, 2695-2707. https://doi.org/10.1093/ icesjms/fsw108

Ferreira, G. V. B., Barletta, M., Lima, A. R. A., Morley, S. A., \& Costa, M. F. (2019). Dynamics of marine debris ingestion by profitable fishes along the estuarine ecocline. Scientific Reports, 9, 1-12. https://doi. org/10.1038/s41598-019-49992-3

Franzellitti, S., Canesi, L., Auguste, M., Wathsala, R. H. G. R., \& Fabbri, E. (2019). Microplastic exposure and effects in aquatic organisms: $A$ physiological perspective. Environmental Toxicology and Pharmacology, 68, 37-51. https://doi.org/10.1016/j.etap.2019.03.009

Frei, S., Piehl, S., Gilfedder, B. S., Löder, M. G. J., Krutzke, J., Wilhelm, L., $\&$ Laforsch, C. (2019). Occurrence of microplastics in the hyporheic zone of rivers. Scientific Reports, 9, 1-11. https://doi.org/10.1038/ s41598-019-51741-5

Froese, R., \& Pauly, D. (2019). FishBase World Wide Web electronic publication, version (12/2019). www.fishbase.org

Galloway, T. S., Cole, M., \& Lewis, C. (2017). Interactions of microplastic debris throughout the marine ecosystem. Nature Ecology and Evolution, 1, 1-8. https://doi.org/10.1038/s41559-017-0116

Garcés-Ordóñez, O., Mejía-Esquivia, K. A., Sierra-Labastidas, T., Patiño, A., Blandón, L. M., \& Espinosa Díaz, L. F. (2020). Prevalence of microplastic contamination in the digestive tract of fishes from mangrove ecosystem in Cispata, Colombian Caribbean. Marine Pollution Bulletin, 154, 111085. https://doi.org/10.1016/j.marpo Ibul.2020.111085

Gies, E. A., LeNoble, J. L., Noël, M., Etemadifar, A., Bishay, F., Hall, E. R., \& Ross, P. S. (2018). Retention of microplastics in a major secondary wastewater treatment plant in Vancouver, Canada. Marine Pollution Bulletin, 133, 553-561. https://doi.org/10.1016/j.marpo Ibul.2018.06.006

Gigault, J., Halle, A. T., Baudrimont, M., Pascal, P.-Y., Gauffre, F., Phi, T.-L., El Hadri, H., Grassl, B., \& Reynaud, S. (2018). Current opinion: What is a nanoplastic? Environmental Pollution, 235, 1030-1034. https://doi. org/10.1016/j.envpol.2018.01.024

Godoy, V., Martín-Lara, M. A., Calero, M., \& Blázquez, G. (2019). Physicalchemical characterization of microplastics present in some exfoliating products from Spain. Marine Pollution Bulletin, 139, 91-99. https:// doi.org/10.1016/j.marpolbul.2018.12.026

Godoy, V., Martín-Lara, M. A., Calero, M., \& Blázquez, G. (2020). The relevance of interaction of chemicals/pollutants and microplastic samples as route for transporting contaminants. Process Safety and 
Environmental Protection, 138, 312-323. https://doi.org/10.1016/j. psep.2020.03.033

Gong, J., \& Xie, P. (2020). Research progress in sources, analytical methods, eco-environmental effects, and control measures of microplastics. Chemosphere, 254, 126790. https://doi.org/10.1016/j.chemo sphere.2020.126790

Gong, M., Yang, G., Zhuang, L., \& Zeng, E. Y. (2019). Microbial biofilm formation and community structure on low-density polyethylene microparticles in lake water microcosms. Environmental Pollution, 252, 94-102. https://doi.org/10.1016/j.envpol.2019.05.090

Gonzalez-Jauregui, M., Borges-Ramirez, M., Barão-Nóbrega, J. A. L., Escamilla, A., Dzul-Caamal, R., \& Rendón-von Osten, J. (2019). Stomach flushing technique applied to quantify microplastics in Crocodilians. MethodsX, 6, 2677-2685. https://doi.org/10.1016/j. mex.2019.11.013

Gouin, T. (2020). Towards improved understanding of the ingestion and trophic transfer of microplastic particles - Critical review and implications for future research. Environmental Toxicology and Chemistry, 39, 1119-1137. https://doi.org/10.1002/etc.4718

Grey, J. (2006). The use of stable isotope analyses in freshwater ecology: Current awareness. Polish Journal of Ecology, 54, 563-584.

Grigorakis, S., Mason, S. A., \& Drouillard, K. G. (2017). Determination of the gut retention of plastic microbeads and microfibers in goldfish (Carassius auratus). Chemosphere, 169, 233-238. https://doi. org/10.1016/j.chemosphere.2016.11.055

Grill, G., Lehner, B., Thieme, M., Geenen, B., Tickner, D., Antonelli, F., Babu, S., Borrelli, P., Cheng, L., Crochetiere, H., Ehalt Macedo, H., Filgueiras, R., Goichot, M., Higgins, J., Hogan, Z., Lip, B., McClain, M. E., Meng, J., Mulligan, M., ... Zarfl, C. (2019). Mapping the world's free-flowing rivers. Nature, 569, 215-221. https://doi.org/10.1038/ s41586-019-1111-9

Guan, J., Qi, K., Wang, J., Wang, W., Wang, Z., Lu, N., \& Qu, J. (2020). Microplastics as an emerging anthropogenic vector of trace metals in freshwater: Significance of biofilms and comparison with natural substrates. Water Research, 184, 116205. https://doi.org/10.1016/j. watres.2020.116205

Guerranti, C., Martellini, T., Perra, G., Scopetani, C., \& Cincinelli, A. (2019). Microplastics in cosmetics: Environmental issues and needs for global bans. Environmental Toxicology and Pharmacology, 68, 7579. https://doi.org/10.1016/j.etap.2019.03.007

Gunaalan, K., Fabbri, E., \& Capolupo, M. (2020). The hidden threat of plastic leachates: A critical review on their impacts on aquatic organisms. Water Research, 184, 116170. https://doi.org/10.1016/j. watres.2020.116170

Guven, O., Bach, L., Munk, P., Dinh, K. V., Mariani, P., \& Nielsen, T. G. (2018). Microplastic does not magnify the acute effect of PAH pyrene on predatory performance of a tropical fish (Lates calcarifer). Aquatic Toxicology, 198, 287-293. https://doi.org/10.1016/j.aquat ox.2018.03.011

Guzzetti, E., Sureda, A., Tejada, S., \& Faggio, C. (2018). Microplastic in marine organism: Environmental and toxicological effects. Environmental Toxicology and Pharmacology, 64, 164-171. https://doi. org/10.1016/j.etap.2018.10.009

Halstead, J. E., Smith, J. A., Carter, E. A., Lay, P. A., \& Johnston, E. L. (2018). Assessment tools for microplastics and natural fibres ingested by fish in an urbanised estuary. Environmental Pollution, 234, 552-561. https://doi.org/10.1016/j.envpol.2017.11.085

Hamed, M., Soliman, H. A. M., Osman, A. G. M., \& Sayed, A. E. D. H. (2019). Assessment the effect of exposure to microplastics in Nile Tilapia (Oreochromis niloticus) early juvenile: I. blood biomarkers. Chemosphere, 228, 345-350. https://doi.org/10.1016/j.chemo sphere.2019.04.153

Hatami, M., Banaee, M., \& Nematdoost Haghi, B. (2019). Sub-lethal toxicity of chlorpyrifos alone and in combination with polyethylene glycol to common carp (Cyprinus carpio). Chemosphere, 219, 981-988. https://doi.org/10.1016/j.chemosphere.2018.12.077

Henry, B., Laitala, K., \& Klepp, I. G. (2019). Microfibres from apparel and home textiles: Prospects for including microplastics in environmental sustainability assessment. Science of the Total Environment, 652, 483-494. https://doi.org/10.1016/j.scitotenv.2018.10.166

Hernandez, E., Nowack, B., \& Mitrano, D. M. (2017). Polyester textiles as a source of microplastics from households: A mechanistic study to understand microfiber release during washing. Environmental Science and Technology, 51, 7036-7046. https://doi.org/10.1021/acs. est.7b01750

Hernandez-Milian, G., Lusher, A., MacGabban, S., \& Rogan, E. (2019). Microplastics in grey seal (Halichoerus grypus) intestines: Are they associated with parasite aggregations? Marine Pollution Bulletin, 146, 349-354. https://doi.org/10.1016/j.marpolbul.2019.06.014

Hidayaturrahman, H., \& Lee, T.-G. (2019). A study on characteristics of microplastic in wastewater of South Korea: Identification, quantification, and fate of microplastics during treatment process. Marine Pollution Bulletin, 146, 696-702. https://doi.org/10.1016/j.marpo Ibul.2019.06.071

Hoang, T. C., \& Felix-Kim, M. (2020). Microplastic consumption and excretion by fathead minnows (Pimephales promelas): Influence of particles size and body shape of fish. Science of the Total Environment, 704, 135433. https://doi.org/10.1016/j.scitotenv.2019.135433

Hoellein, T. J., Shogren, A. J., Tank, J. L., Risteca, P., \& Kelly, J. J. (2019). Microplastic deposition velocity in streams follows patterns for naturally occurring allochthonous particles. Scientific Reports, 9, 1-11. https://doi.org/10.1038/s41598-019-40126-3

Horton, A. A., Jürgens, M. D., Lahive, E., van Bodegom, P. M., \& Vijver, M. G. (2018). The influence of exposure and physiology on microplastic ingestion by the freshwater fish Rutilus rutilus (roach) in the River Thames, UK. Environmental Pollution, 236, 188-194. https://doi. org/10.1016/j.envpol.2018.01.044

Horton, A. A., Svendsen, C., Williams, R. J., Spurgeon, D. J., \& Lahive, E. (2017). Large microplastic particles in sediments of tributaries of the River Thames, UK - Abundance, sources and methods for effective quantification. Marine Pollution Bulletin, 114, 218-226. https://doi. org/10.1016/j.marpolbul.2016.09.004

Huang, J.-S., Koongolla, J. B., Li, H.-X., Lin, L., Pan, Y.-F., Liu, S., He, W.H., Maharana, D., \& Xu, X.-R. (2020). Microplastic accumulation in fish from Zhanjiang mangrove wetland, South China. Science of the Total Environment, 708, 134839. https://doi.org/10.1016/j.scito tenv.2019.134839

Huang, Q., Lin, Y., Zhong, Q., Ma, F., \& Zhang, Y. (2020). The impact of microplastic particles on population dynamics of predator and prey: Implication of the Lotka-Volterra model. Scientific Reports, 10, 1-10. https://doi.org/10.1038/s41598-020-61414-3

Huang, Y., Qing, X., Wang, W., Han, G., \& Wang, J. (2020). Mini-review on current studies of airborne microplastics: Analytical methods, occurrence, sources, fate and potential risk to human beings. TrAC -. Trends in Analytical Chemistry, 125, 115821. https://doi.org/10.1016/j. trac. 2020.115821

Hurt, R., O'Reilly, C. M., \& Perry, W. L. (2020). Microplastic prevalence in two fish species in two U.S. reservoirs. Limnology and Oceanography Letters, 5, 147-153. https://doi.org/10.1002/ lol2.10140

Huuskonen, H., Subiron i Folguera, J., Kortet, R., Akkanen, J., Vainikka, A., Janhunen, M., \& Kekäläinen, J. (2020). Do whitefish (Coregonus lavaretus) larvae show adaptive variation in the avoidance of microplastic ingestion? Environmental Pollution, 262, 114353, https://doi. org/10.1016/j.envpol.2020.114353

Iheanacho, S. C., \& Odo, G. E. (2020). Neurotoxicity, oxidative stress biomarkers and haematological responses in African catfish (Clarias gariepinus) exposed to polyvinyl chloride microparticles. Comparative 
Biochemistry and Physiology Part - C: Toxicology and Pharmacology, 232, 108741. https://doi.org/10.1016/j.cbpc.2020.108741

Jabeen, K., Li, B., Chen, Q., Su, L., Wu, C., Hollert, H., \& Shi, H. (2018). Effects of virgin microplastics on goldfish (Carassius auratus). Chemosphere, 213, 323-332. https://doi.org/10.1016/j.chemo sphere.2018.09.031

Jabeen, K., Su, L., Li, J., Yang, D., Tong, C., Mu, J., \& Shi, H. (2017). Microplastics and mesoplastics in fish from coastal and fresh waters of China. Environmental Pollution, 221, 141-149. https://doi. org/10.1016/j.envpol.2016.11.055

Jackson, M. C., Donohue, I., Jackson, A. L., Britton, J. R., Harper, D. M., \& Grey, J. (2012). Population-level metrics of trophic structure based on stable isotopes and their application to invasion ecology. PLoS One, 7, e31757. https://doi.org/10.1371/journal.pone.0031757

Jackson, M. C., Loewen, C. J. G., Vinebrooke, R. D., \& Chimimba, C. T. (2016). Net effects of multiple stressors in freshwater ecosystems: A meta-analysis. Global Change Biology, 22, 180-189. https://doi. org/10.1111/gcb.13028

Jâms, I. B., Windsor, F. M., Poudevigne-Durance, T., Ormerod, S. J., \& Durance, I. (2020). Estimating the size distribution of plastics ingested by animals. Nature Communications, 11, 1594. https://doi. org/10.1038/s41467-020-15406-6

Janaina, A. K., Miguel, P., Davi, B. G., \& Barrella, W. (2020). Textile sustainability: A Brazilian etiquette issue. Environmental Science and Policy, 109, 125-130. https://doi.org/10.1016/j.envsci.2020.02.025

Jin, Y., Xia, J., Pan, Z., Yang, J., Wang, W., \& Fu, Z. (2018). Polystyrene microplastics induce microbiota dysbiosis and inflammation in the gut of adult zebrafish. Environmental Pollution, 235, 322-329. https://doi. org/10.1016/j.envpol.2017.12.088

Jobling, M. (1981). The influences of feeding on the metabolic rate of fishes: A short review. Journal of Fish Biology, 18, 385-400. https:// doi.org/10.1111/j.1095-8649.1981.tb03780.x

Jovanović, B. (2017). Ingestion of microplastics by fish and its potential consequences from a physical perspective. Integrated Environmental Assessment and Management, 13, 510-515. https://doi.org/10.1002/ ieam.1913

Kalčíková, G. (2020). Aquatic vascular plants - A forgotten piece of nature in microplastic research. Environmental Pollution, 262, 114354. https://doi.org/10.1016/j.envpol.2020.114354

Kamler, J. F., \& Pope, K. L. (2001). Nonlethal methods of examining fish stomach contents. Reviews in Fisheries Science, 9, 1-11. https://doi. org/10.1080/20016491101663

Karami, A., Golieskardi, A., Choo, C. K., Romano, N., Ho, Y. B., \& Salamatinia, B. (2017). A high-performance protocol for extraction of microplastics in fish. Science of the Total Environment, 578, 485-494. https://doi.org/10.1016/j.scitotenv.2016.10.213

Karami, A., Romano, N., Galloway, T., \& Hamzah, H. (2016). Virgin microplastics cause toxicity and modulate the impacts of phenanthrene on biomarker responses in African catfish (Clarias gariepinus). Environmental Research, 151, 58-70. https://doi.org/10.1016/j. envres.2016.07.024

Karbalaei, S., Hanachi, P., Walker, T. R., \& Cole, M. (2018). Occurrence, sources, human health impacts and mitigation of microplastic pollution. Environmental Science and Pollution Research, 25, 36046-36063. https://doi.org/10.1007/s11356-018-3508-7

Kasamesiri, P., \& Thaimuangphol, W. (2020). Microplastics ingestion by freshwater fish in the Chi River, Thailand. International Journal of GEOMATE, 18, 114-119. https://doi.org/10.21660/2020.67.9110

Kataoka, T., Nihei, Y., Kudou, K., \& Hinata, H. (2019). Assessment of the sources and inflow processes of microplastics in the river environments of Japan. Environmental Pollution, 244, 958-965. https://doi. org/10.1016/j.envpol.2018.10.111

Katyal, D., Kong, E., \& Villanueva, J. (2020). Microplastics in the environment: Impact on human health and future mitigation strategies.
Environmental Health Review, 63, 27-31. https://doi.org/10.5864/ d2020-005

Kazour, M., \& Amara, R. (2020). Is blue mussel caging an efficient method for monitoring environmental microplastics pollution? Science of the Total Environment, 710, 135649. https://doi.org/10.1016/j.scito tenv.2019.135649

Kazour, M., Jemaa, S., El Rakwe, M., Duflos, G., Hermabassiere, L., Dehaut, A., Le Bihanic, F., Cachot, J., Cornille, V., Rabhi, K., Khalaf, G., \& Amara, R. (2018). Juvenile fish caging as a tool for assessing microplastics contamination in estuarine fish nursery grounds. Environmental Science and Pollution Research, 27, 3548-3559. https:// doi.org/10.1007/s11356-018-3345-8

Khan, F. R., Boyle, D., Chang, E., \& Bury, N. R. (2017). Do polyethylene microplastic beads alter the intestinal uptake of $\mathrm{Ag}$ in rainbow trout (Oncorhynchus mykiss)? Analysis of the MP vector effect using in vitro gut sacs. Environmental Pollution, 231, 200-206. https://doi. org/10.1016/j.envpol.2017.08.019

Khan, F. R., Shashoua, Y., Crawford, A., Drury, A., Sheppard, K., Stewart, K., \& Sculthorp, T. (2020). 'The Plastic Nile': First evidence of microplastic contamination in fish from the Nile River (Cairo, Egypt. Toxics, 8, 22. https://doi.org/10.3390/toxics8020022

Kim, S. W., Chae, Y., Kim, D., \& An, Y. J. (2019). Zebrafish can recognize microplastics as inedible materials: Quantitative evidence of ingestion behavior. Science of the Total Environment, 649, 156-162. https:// doi.org/10.1016/j.scitotenv.2018.08.310

Knight, L. J., Parker-Jurd, F. N. F., Al-Sid-Cheikh, M., \& Thompson, R. C. (2020). Tyre wear particles: An abundant yet widely unreported microplastic? Environmental Science and Pollution Research, 27, 1834518354. https://doi.org/10.1007/s11356-020-08187-4

Kundungal, H., Gangarapu, M., Sarangapani, S., Patchaiyappan, A., \& Devipriya, S. P. (2019). Efficient biodegradation of polyethylene (HDPE) waste by the plastic-eating lesser waxworm (Achroia grisella). Environmental Science and Pollution Research, 26, 18509-18519. https://doi.org/10.1007/s11356-019-05038-9

Kurniawan, S. B., \& Imron, M. F. (2019). Seasonal variation of plastic debris accumulation in the estuary of Wonorejo River. Surabaya, Indonesia. Environmental Technology and Innovation, 16, 100490. https://doi.org/10.1016/j.eti.2019.100490

Kuśmierek, N., \& Popiołek, M. (2020). Microplastics in freshwater fish from Central European lowland river (Widawa R., SW Poland). Environmental Science and Pollution Research, 27, 11438-11442. https://doi.org/10.1007/s11356-020-08031-9

LaPlaca, S. B., \& van den Hurk, P. (2020). Toxicological effects of micronized tire crumb rubber on mummichog (Fundulus heteroclitus) and fathead minnow (Pimephales promelas). Ecotoxicology, 29, 524-534. https://doi.org/10.1007/s10646-020-02210-7

Lee, H., \& Kim, Y. (2018). Treatment characteristics of microplastics at biological sewage treatment facilities in Korea. Marine Pollution Bulletin, 137, 1-8. https://doi.org/10.1016/j.marpo Ibul.2018.09.050

Lee, H., Lee, H. J., \& Kwon, J. H. (2019). Estimating microplastic-bound intake of hydrophobic organic chemicals by fish using measured desorption rates to artificial gut fluid. Science of the Total Environment, 651, 162-170. https://doi.org/10.1016/j.scitotenv.2018.09.068

Lei, L., Wu, S., Lu, S., Liu, M., Song, Y., Fu, Z., Shi, H., Raley-Susman, K. M., \& He, D. (2018). Microplastic particles cause intestinal damage and other adverse effects in zebrafish Danio rerio and nematode Caenorhabditis elegans. Science of the Total Environment, 619-620, 1-8. https://doi.org/10.1016/j.scitotenv.2017.11.103

LeMoine, C. M. R., Kelleher, B. M., Lagarde, R., Northam, C., Elebute, O. O., \& Cassone, B. J. (2018). Transcriptional effects of polyethylene microplastics ingestion in developing zebrafish (Danio rerio). Environmental Pollution, 243, 591-600. https://doi.org/10.1016/j. envpol.2018.08.084 
Lester, R. J. G., \& McVinish, R. (2016). Does moving up a food chain increase aggregation in parasites? Journal of the Royal Society Interface, 13, 1-11. https://doi.org/10.1098/rsif.2016.0102

Li, B., Su, L., Zhang, H., Deng, H., Chen, Q., \& Shi, H. (2020). Microplastics in fishes and their living environments surrounding a plastic production area. Science of the Total Environment, 727, 138662. https://doi. org/10.1016/j.scitotenv.2020.138662

Li, C., Busquets, R., \& Campos, L. C. (2020). Assessment of microplastics in freshwater systems: A review. Science of the Total Environment, 707, 135578. https://doi.org/10.1016/j.scitotenv.2019.135578

Li, J., Liu, H., \& Paul Chen, J. (2018). Microplastics in freshwater systems: A review on occurrence, environmental effects, and methods for microplastics detection. Water Research, 137, 362-374. https://doi. org/10.1016/j.watres.2017.12.056

Li, L. U., Geng, S., Wu, C., Song, K., Sun, F., Visvanathan, C., Xie, F., \& Wang, Q. (2019). Microplastics contamination in different trophic state lakes along the middle and lower reaches of Yangtze River Basin. Environmental Pollution, 254, 112951. https://doi.org/10.1016/j. envpol.2019.07.119

Li, X., Mei, Q., Chen, L., Zhang, H., Dong, B., Dai, X., He, C., \& Zhou, J. (2019). Enhancement in adsorption potential of microplastics in sewage sludge for metal pollutants after the wastewater treatment process. Water Research, 157, 228-237. https://doi.org/10.1016/j. watres.2019.03.069

Li, Y., Zhang, H., \& Tang, C. (2020). A review of possible pathways of marine microplastics transport in the ocean. Anthropocene Coasts, 3 , 6-13. https://doi.org/10.1139/anc-2018-0030

Limonta, G., Mancia, A., Benkhalqui, A., Bertolucci, C., Abelli, L., Fossi, M. C., \& Panti, C. (2019). Microplastics induce transcriptional changes, immune response and behavioral alterations in adult zebrafish. Scientific Reports, 9, 1-11. https://doi.org/10.1038/s41598-01952292-5

Liu, C., Li, J., Zhang, Y., Wang, L., Deng, J., Gao, Y., Yu, L. U., Zhang, J., \& Sun, H. (2019). Widespread distribution of PET and PC microplastics in dust in urban China and their estimated human exposure. Environment International, 128, 116-124. https://doi.org/10.1016/j. envint.2019.04.024

Liu, G., Zhu, Z., Yang, Y., Sun, Y., Yu, F., \& Ma, J. (2019). Sorption behavior and mechanism of hydrophilic organic chemicals to virgin and aged microplastics in freshwater and seawater. Environmental Pollution, 246, 26-33. https://doi.org/10.1016/j. envpol.2018.11.100

Lu, Y., Zhang, Y., Deng, Y., Jiang, W., Zhao, Y., Geng, J., \& Ren, H. (2016). Uptake and accumulation of polystyrene microplastics in zebrafish (Danio rerio) and toxic effects in liver. Environmental Science and Technology, 50, 4054-4060. https://doi.org/10.1021/acs. est.6b00183

Luís, L. G., Ferreira, P., Fonte, E., Oliveira, M., \& Guilhermino, L. (2015). Does the presence of microplastics influence the acute toxicity of chromium(VI) to early juveniles of the common goby (Pomatoschistus microps)? A study with juveniles from two wild estuarine populations. Aquatic Toxicology, 164, 163-174. https://doi.org/10.1016/j.aquat ox.2015.04.018

Lusher, A. L., Welden, N. A., Sobral, P., \& Cole, M. (2017). Sampling, isolating and identifying microplastics ingested by fish and invertebrates. Analytical Methods, 9, 1346-1360. https://doi.org/10.1039/ c6ay $02415 \mathrm{~g}$

Lv, W., Zhou, W., Lu, S., Huang, W., Yuan, Q., Tian, M., Lv, W., \& He, D. (2019). Microplastic pollution in rice-fish co-culture system: A report of three farmland stations in Shanghai, China. Science of the Total Environment, 652, 1209-1218. https://doi.org/10.1016/j.scito tenv.2018.10.321

Magadini, D. L., Goes, J. I., Ortiz, S., Lipscomb, J., Pitiranggon, M., \& Yan, B. (2020). Assessing the sorption of pharmaceuticals to microplastics through in-situ experiments in New York City waterways. Science of the Total Environment, 729, 138766. https://doi.org/10.1016/j.scito tenv.2020.138766

Mak, C. W., Ching-Fong Yeung, K., \& Chan, K. M. (2019). Acute toxic effects of polyethylene microplastic on adult zebrafish. Ecotoxicology and Environmental Safety, 182, 109442. https://doi.org/10.1016/j. ecoenv.2019.109442

Malinich, T. D., Chou, N., Sepúlveda, M. S., \& Höök, T. O. (2018). No evidence of microplastic impacts on consumption or growth of larval Pimephales promelas. Environmental Toxicology and Chemistry, 37, 2912-2918. https://doi.org/10.1002/etc.4257

Malizia, A., \& Monmany-Garzia, A. C. (2019). Terrestrial ecologists should stop ignoring plastic pollution in the Anthropocene time. Science of the Total Environment, 668, 1025-1029. https://doi.org/10.1016/j. scitotenv.2019.03.044

Markic, A., Gaertner, J. C., Gaertner-Mazouni, N., \& Koelmans, A. A. (2020). Plastic ingestion by marine fish in the wild. Critical Reviews in Environmental Science and Technology, 50, 657-697. https://doi. org/10.1080/10643389.2019.1631990

Mattsson, K., Ekvall, M. T., Hansson, L. A., Linse, S., Malmendal, A., \& Cedervall, T. (2015). Altered behavior, physiology, and metabolism in fish exposed to polystyrene nanoparticles. Environmental Science and Technology, 49, 553-561. https://doi.org/10.1021/es5053655

Mazurais, D., Ernande, B., Quazuguel, P., Severe, A., Huelvan, C., Madec, L., Mouchel, O., Soudant, P., Robbens, J., Huvet, A., \& ZamboninoInfante, J. (2015). Evaluation of the impact of polyethylene microbeads ingestion in European sea bass (Dicentrarchus labrax) larvae. Marine Environmental Research, 112, 78-85. https://doi. org/10.1016/j.marenvres.2015.09.009

Mbedzi, R., Dalu, T., Wasserman, R. J., Murungweni, F., \& Cuthbert, R. N. (2019). Functional response quantifies microplastic uptake by a widespread African fish species. Science of the Total Environment, 700, 134522. https://doi.org/10.1016/j.scitotenv.2019.134522

McGoran, A. R., Clark, P. F., \& Morritt, D. (2017). Presence of microplastic in the digestive tracts of European flounder, Platichthys flesus, and European smelt, Osmerus eperlanus, from the River Thames. Environmental Pollution, 220, 744-751. https://doi.org/10.1016/j. envpol.2016.09.078

McGoran, A. R., Cowie, P. R., Clark, P. F., McEvoy, J. P., \& Morritt, D. (2018). Ingestion of plastic by fish: A comparison of Thames Estuary and Firth of Clyde populations. Marine Pollution Bulletin, 137, 12-23. https://doi.org/10.1016/j.marpolbul.2018.09.054

McNeish, R. E., Kim, L. H., Barrett, H. A., Mason, S. A., Kelly, J. J., \& Hoellein, T. J. (2018). Microplastic in riverine fish is connected to species traits. Scientific Reports, 8, 11639. https://doi.org/10.1038/ s41598-018-29980-9

Mohajerani, A., \& Karabatak, B. (2020). Microplastics and pollutants in biosolids have contaminated agricultural soils: An analytical study and a proposal to cease the use of biosolids in farmlands and utilise them in sustainable bricks. Waste Management, 107, 252-265. https://doi.org/10.1016/j.wasman.2020.04.021

Morritt, D., Stefanoudis, P. V., Pearce, D., Crimmen, O. A., \& Clark, P. F. (2014). Plastic in the Thames: A river runs through it. Marine Pollution Bulletin, 78, 196-200. https://doi.org/10.1016/j.marpolbul.2013.10.035

Munier, B., \& Bendell, L. I. (2018). Macro and micro plastics sorb and desorb metals and act as a point source of trace metals to coastal ecosystems. PLoS One, 13, e0191759. https://doi.org/10.1371/journ al.pone.0191759

Naidoo, T., \& Glassom, D. (2019). Decreased growth and survival in small juvenile fish, after chronic exposure to environmentally relevant concentrations of microplastic. Marine Pollution Bulletin, 145, 254-259. https://doi.org/10.1016/j.marpolbul.2019.02.037

Naidoo, T., Goordiyal, K., \& Glassom, D. (2017). Are nitric acid (HNO3) digestions efficient in isolating microplastics from juvenile fish? Water, Air, and Soil Pollution, 228, 1-11. https://doi.org/10.1007/s1127 0-017-3654-4 
Naidoo, T., Sershen, X. X. Thompson, R. C., \& Rajkaran, A. (2020). Quantification and characterisation of microplastics ingested by selected juvenile fish species associated with mangroves in KwaZuluNatal, South Africa. Environmental Pollution, 257, 113635. https://doi. org/10.1016/j.envpol.2019.113635

Naidoo, T., Smit, A. J., \& Glassom, D. (2016). Plastic ingestion by estuarine mullet Mugil cephalus (Mugilidae) in an urban harbour, KwaZuluNatal, South Africa. African Journal of Marine Science, 38, 145-149. https://doi.org/10.2989/1814232X.2016.1159616

Napper, I. E., \& Thompson, R. C. (2016). Release of synthetic microplastic plastic fibres from domestic washing machines: Effects of fabric type and washing conditions. Marine Pollution Bulletin, 112, 39-45. https://doi.org/10.1016/j.marpolbul.2016.09.025

Ngo, P. L., Pramanik, B. K., Shah, K., \& Roychand, R. (2019). Pathway, classification and removal efficiency of microplastics in wastewater treatment plants. Environmental Pollution, 255, 113326. https://doi. org/10.1016/j.envpol.2019.113326

Nizzetto, L., Bussi, G., Futter, M. N., Butterfield, D., \& Whitehead, P. G. (2016). A theoretical assessment of microplastic transport in river catchments and their retention by soils and river sediments. Environmental Science: Processes and Impacts, 18, 1050-1059. https:// doi.org/10.1039/c6em00206d

Noble, R. A. A., Cowx, I. G., Goffaux, D., \& Kestemont, P. (2007). Assessing the health of European rivers using functional ecological guilds of fish communities: Standardising species classification and approaches to metric selection. Fisheries Management and Ecology, 14, 381-392. https://doi. org/10.1111/j.1365-2400.2007.00575.x

O'Connor, D., Pan, S., Shen, Z., Song, Y., Jin, Y., Wu, W. M., \& Hou, D. (2019). Microplastics undergo accelerated vertical migration in sand soil due to small size and wet-dry cycles. Environmental Pollution, 249, 527-534. https://doi.org/10.1016/j.envpol.2019.03.092

Ockelford, A., Cundy, A., \& Ebdon, J. E. (2020). Storm response of fluvial sedimentary microplastics. Scientific Reports, 10, 1865. https://doi. org/10.1038/s41598-020-58765-2

Oliveira, M., Almeida, M., \& Miguel, I. (2019). A micro(nano)plastic boomerang tale: A never ending story? TrAC - Trends in Analytical Chemistry, 112, 196-200. https://doi.org/10.1016/j.trac.2019.01.005

Oliveira, M., Ribeiro, A., Hylland, K., \& Guilhermino, L. (2013). Single and combined effects of microplastics and pyrene on juveniles ( $0+$ group) of the common goby Pomatoschistus microps (Teleostei, Gobiidae). Ecological Indicators, 34, 641-647. https://doi.org/10.1016/j.ecoli nd.2013.06.019

Ormerod, S. J., Dobson, M., Hildrew, A. G., \& Townsend, C. R. (2010). Multiple stressors in freshwater ecosystems. Freshwater Biology, 55, 1-4. https://doi.org/10.1111/j.1365-2427.2009.02395.x

Pannetier, P., Morin, B., Le Bihanic, F., Dubreil, L., Clérandeau, C., Chouvellon, F., Van Arkel, K., Danion, M., \& Cachot, J. (2020). Environmental samples of microplastics induce significant toxic effects in fish larvae. Environment International, 134, 105047. https:// doi.org/10.1016/j.envint.2019.105047

Park, T. J., Lee, S. H., Lee, M. S., Lee, J. K., Lee, S. H., \& Zoh, K. D. (2020). Occurrence of microplastics in the Han River and riverine fish in South Korea. Science of the Total Environment, 708, 134535. https:// doi.org/10.1016/j.scitotenv.2019.134535

Parker, G. A. (1992). The evolution of sexual size dimorphism in fish. Journal of Fish Biology, 41, 1-20. https://doi.org/10.1111/j.1095-8649.1992. tb03864.x

Pazos, R. S., Maiztegui, T., Colautti, D. C., Paracampo, A. H., \& Gómez, N. (2017). Microplastics in gut contents of coastal freshwater fish from Río de la Plata estuary. Marine Pollution Bulletin, 122, 85-90. https:// doi.org/10.1016/j.marpolbul.2017.06.007

Pegado, T. S. E. S., Schmid, K., Winemiller, K. O., Chelazzi, D., Cincinelli, A., Dei, L., \& Giarrizzo, T. (2018). First evidence of microplastic ingestion by fishes from the Amazon River estuary. Marine
Pollution Bulletin, 133, 814-821. https://doi.org/10.1016/j.marpo Ibul.2018.06.035

Peters, C. A., \& Bratton, S. P. (2016). Urbanization is a major influence on microplastic ingestion by sunfish in the Brazos River Basin, Central Texas, USA. Environmental Pollution, 210, 380-387. https://doi. org/10.1016/j.envpol.2016.01.018

Phillips, M. B., \& Bonner, T. H. (2015). Occurrence and amount of microplastic ingested by fishes in watersheds of the Gulf of Mexico. Marine Pollution Bulletin, 100, 264-269. https://doi.org/10.1016/j. marpolbul.2015.08.041

Piñon-Colin, T. J., Rodriguez-Jimenez, R., Rogel-Hernandez, E., AlvarezAndrade, A., \& Wakida, F. T. (2020). Microplastics in stormwater runoff in a semiarid region, Tijuana, Mexico. Science of the Total Environment, 704, 135411. https://doi.org/10.1016/j.scito tenv.2019.135411

Possatto, F. E., Barletta, M., Costa, M. F., Ivar do Sul, J. A., \& Dantas, D. V. (2011). Plastic debris ingestion by marine catfish: An unexpected fisheries impact. Marine Pollution Bulletin, 62, 1098-1102. https://doi. org/10.1016/j.marpolbul.2011.01.036

Prata, J. C., da Costa, J. P., Lopes, I., Duarte, A. C., \& Rocha-Santos, T. (2020). Environmental exposure to microplastics: An overview on possible human health effects. Science of the Total Environment, 702, 134455. https://doi.org/10.1016/j.scitotenv.2019.134455

Procter, J., Hopkins, F. E., Fileman, E. S., \& Lindeque, P. K. (2019). Smells good enough to eat: Dimethyl sulfide (DMS) enhances copepod ingestion of microplastics. Marine Pollution Bulletin, 138, 1-6. https:// doi.org/10.1016/j.marpolbul.2018.11.014

Prokić, M. D., Radovanović, T. B., Gavrić, J. P., \& Faggio, C. (2019). Ecotoxicological effects of microplastics: Examination of biomarkers, current state and future perspectives. TrAC - Trends in Analytical Chemistry, 111, 37-46. https://doi.org/10.1016/j.trac.2018.12.001

Qiang, L., \& Cheng, J. (2019). Exposure to microplastics decreases swimming competence in larval zebrafish (Danio rerio). Ecotoxicology and Environmental Safety, 176, 226-233. https://doi.org/10.1016/j. ecoenv.2019.03.088

Qiao, R., Deng, Y., Zhang, S., Borri, M., Zhu, Q., Ren, H., \& Zhang, Y. (2019). Accumulation of different shapes of microplastics initiates intestinal injury and gut microbiota dysbiosis in the gut of zebra fish. Chemosphere, 236, 124334. https://doi.org/10.1016/j.chemo sphere.2019.07.065

Qiao, R., Lu, K., Deng, Y., Ren, H., \& Zhang, Y. (2019). Combined effects of polystyrene microplastics and natural organic matter on the accumulation and toxicity of copper in zebrafish. Science of the Total Environment, 682, 128-137. https://doi.org/10.1016/j.scito tenv.2019.05.163

Qu, H., Ma, R., Wang, B., Yang, J., Duan, L., \& Yu, G. (2019). Enantiospecific toxicity, distribution and bioaccumulation of chiral antidepressant venlafaxine and its metabolite in loach (Misgurnus anguillicaudatus) co-exposed to microplastic and the drugs. Journal of Hazardous Materials, 370, 203-211. https://doi.org/10.1016/j.jhazm at.2018.04.041

Quinn, B., Murphy, F., \& Ewins, C. (2017). Validation of density separation for the rapid recovery of microplastics from sediment. Analytical Methods, 9, 1491-1498. https://doi.org/10.1039/c6ay0 $2542 \mathrm{k}$

Raddadi, N., \& Fava, F. (2019). Biodegradation of oil-based plastics in the environment: Existing knowledge and needs of research and innovation. Science of the Total Environment, 679, 148-158. https://doi. org/10.1016/j.scitotenv.2019.04.419

Rainieri, S., \& Barranco, A. (2019). Microplastics, a food safety issue? Trends in Food Science and Technology, 84, 55-57. https://doi. org/10.1016/j.tifs.2018.12.009

Ramos, J., Barletta, M., \& Costa, M. (2012). Ingestion of nylon threads by Gerreidae while using a tropical estuary as foraging grounds. Aquatic Biology, 17, 29-34. https://doi.org/10.3354/ab00461 
Re, V. (2019). Shedding light on the invisible: Addressing the potential for groundwater contamination by plastic microfibers. Hydrogeology Journal, 27, 2719-2727. https://doi.org/10.1007/s10040-019-01998 $-x$

Reid, A. J., Carlson, A. K., Creed, I. F., Eliason, E. J., Gell, P. A., Johnson, P. T. J., Kidd, K. A., MacCormack, T. J., Olden, J. D., Ormerod, S. J., Smol, J. P., Taylor, W. W., Tockner, K., Vermaire, J. C., Dudgeon, D., \& Cooke, S. J. (2019). Emerging threats and persistent conservation challenges for freshwater biodiversity. Biological Reviews, 94, 849873. https://doi.org/10.1111/brv.12480

Renner, G., Nellessen, A., Schwiers, A., Wenzel, M., Schmidt, T. C., \& Schram, J. (2019). Data preprocessing \& evaluation used in the microplastics identification process: A critical review \& practical guide. TrAC - Trends in Analytical Chemistry, 111, 229-238. https://doi. org/10.1016/j.trac.2018.12.004

Ribeiro, F., O'Brien, J. W., Galloway, T., \& Thomas, K. V. (2019). Accumulation and fate of nano- and micro-plastics and associated contaminants in organisms. TrAC - Trends in Analytical Chemistry, 111, 139-147. https://doi.org/10.1016/j.trac.2018.12.010

Roberts, H. E., Palmeiro, B., \& Weber, E. S. (2009). Bacterial and parasitic diseases of pet fish. Veterinary Clinics of North America - Exotic Animal Practice, 12, 609-638. https://doi.org/10.1016/j.cvex.2009.06.010

Roch, S., \& Brinker, A. (2017). Rapid and efficient method for the detection of microplastic in the gastrointestinal tract of fishes. Environmental Science and Technology, 51, 4522-4530. https://doi. org/10.1021/acs.est.7b00364

Roch, S., Friedrich, C., \& Brinker, A. (2020). Uptake routes of microplastics in fishes: Practical and theoretical approaches to test existing theories. Scientific Reports, 10, 1-12. https://doi.org/10.1038/s4159 8-020-60630-1

Roch, S., Walter, T., Ittner, L. D., Friedrich, C., \& Brinker, A. (2019). A systematic study of the microplastic burden in freshwater fishes of south-western Germany - Are we searching at the right scale? Science of the Total Environment, 689, 1001-1011. https://doi.org/10.1016/j. scitotenv.2019.06.404

Rochman, C. M., Kurobe, T., Flores, I., \& Teh, S. J. (2014). Early warning signs of endocrine disruption in adult fish from the ingestion of polyethylene with and without sorbed chemical pollutants from the marine environment. Science of the Total Environment, 493, 656-661. https://doi.org/10.1016/j.scitotenv.2014.06.051

Rochman, C. M., Parnis, J. M., Browne, M. A., Serrato, S., Reiner, E. J., Robson, M., Young, T., Diamond, M. L., \& Teh, S. J. (2017). Direct and indirect effects of different types of microplastics on freshwater prey (Corbicula fluminea) and their predator (Acipenser transmontanus). PLoS One, 12, e0187664. https://doi.org/10.1371/journ al.pone.0187664

Roda, J. F. B., Lauer, M. M., Risso, W. E., dos Reis, B., \& Martinez, C. (2020). Microplastics and copper effects on the neotropical teleost Prochilodus lineatus: Is there any interaction? Comparative Biochemistry and Physiology Part A: Molecular \& Integrative Physiology, 242, 110659, https://doi.org/10.1016/j.cbpa.2020.110659

Rodrigues, M. O., Abrantes, N., Gonçalves, F. J. M., Nogueira, H., Marques, J. C., \& Gonçalves, A. M. M. (2019). Impacts of plastic products used in daily life on the environment and human health: What is known? Environmental Toxicology and Pharmacology, 72, 103239, https://doi. org/10.1016/j.etap.2019.103239

Rolsky, C., Kelkar, V., Driver, E., \& Halden, R. U. (2020). Municipal sewage sludge as a source of microplastics in the environment. Current Opinion in Environmental Science and Health, 14, 16-22. https://doi. org/10.1016/j.coesh.2019.12.001

Romano, N., Ashikin, M., Teh, J. C., Syukri, F., \& Karami, A. (2018). Effects of pristine polyvinyl chloride fragments on whole body histology and protease activity in silver barb Barbodes gonionotus fry. Environmental Pollution, 237, 1106-1111. https://doi.org/10.1016/j. envpol.2017.11.040
Roychand, R., \& Pramanik, B. K. (2020). Identification of micro-plastics in Australian road dust. Journal of Environmental. Chemical Engineering, 8, 103647. https://doi.org/10.1016/j.jece.2019.103647

Ryan, M. G., Watkins, L., \& Walter, M. T. (2019). Hudson River juvenile blueback herring avoid ingesting microplastics. Marine Pollution Bulletin, 146, 935-939. https://doi.org/10.1016/j.marpo Ibul.2019.07.004

Sánchez, C. (2019). Fungal potential for the degradation of petroleum-based polymers: An overview of macro- and microplastics biodegradation. Biotechnology Advances, 40, 107501. https://doi. org/10.1016/j.biotechadv.2019.107501

Sanchez, W., Bender, C., \& Porcher, J. M. (2014). Wild gudgeons (Gobio gobio) from French rivers are contaminated by microplastics: Preliminary study and first evidence. Environmental Research, 128, 98-100. https://doi.org/10.1016/j.envres.2013.11.004

Savoca, M. S., Tyson, C. W., McGill, M., \& Slager, C. J. (2017). Odours from marine plastic debris induce food search behaviours in a forage fish. Proceedings of the Royal Society B: Biological Sciences, 284, 20171000. https://doi.org/10.1098/rspb.2017.1000

Schür, C., Rist, S., Baun, A., Mayer, P., Hartmann, N. B., \& Wagner, M. (2019). When fluorescence is not a particle: The tissue translocation of microplastics in Daphnia magna seems an artifact. Environmental Toxicology and Chemistry, 38, 1495-1503. https://doi.org/10.1002/ etc.4436

Scopetani, C., Esterhuizen-Londt, M., Chelazzi, D., Cincinelli, A., Setälä, H., \& Pflugmacher, S. (2020). Self-contamination from clothing in microplastics research. Ecotoxicology and Environmental Safety, 189, 110036. https://doi.org/10.1016/j.ecoenv.2019.110036

Setälä, O., Fleming-Lehtinen, V., \& Lehtiniemi, M. (2014). Ingestion and transfer of microplastics in the planktonic food web. Environmental Pollution, 185, 77-83. https://doi.org/10.1016/j.envpol.2013.10.013

Shen, M., Zhu, Y., Zhang, Y., Zeng, G., Wen, X., Yi, H., Ye, S., Ren, X., \& Song, B. (2019). Micro(nano)plastics: Unignorable vectors for organisms. Marine Pollution Bulletin, 139, 328-331. https://doi. org/10.1016/j.marpolbul.2019.01.004

Silva, J. D. B., Barletta, M., Lima, A. R. A., \& Ferreira, G. V. B. (2018). Use of resources and microplastic contamination throughout the life cycle of grunts (Haemulidae) in a tropical estuary. Environmental Pollution, 242, 1010-1021. https://doi. org/10.1016/j.envpol.2018.07.038

Silva-Cavalcanti, J. S., Silva, J. D. B., de França, E. J., de Araújo, M. C. B., \& Gusmão, F. (2017). Microplastics ingestion by a common tropical freshwater fishing resource. Environmental Pollution, 221, 218-226. https://doi.org/10.1016/j.envpol.2016.11.068

Simon-Sánchez, L., Grelaud, M., Garcia-Orellana, J., \& Ziveri, P. (2019). River deltas as hotspots of microplastic accumulation: The case study of the Ebro River (NW Mediterranean). Science of the Total Environment, 687, 1186-1196. https://doi.org/10.1016/j.scito tenv.2019.06.168

Slootmaekers, B., Catarci Carteny, C., Belpaire, C., Saverwyns, S., Fremout, W., Blust, R., \& Bervoets, L. (2019). Microplastic contamination in gudgeons (Gobio gobio) from Flemish rivers (Belgium). Environmental Pollution, 244, 675-684. https://doi.org/10.1016/j. envpol.2018.09.136

Song, J., Hou, C., Zhou, Y., Liu, Q., Wu, X., Wang, Y., \& Yi, Y. (2020). The flowing of microplastics was accelerated under the influence of artificial flood generated by hydropower station. Journal of Cleaner Production, 255, 120174. https://doi.org/10.1016/j.jclep ro.2020.120174

Song, J., Jongmans-Hochschulz, E., Mauder, N., Imirzalioglu, C., Wichels, A., \& Gerdts, G. (2020). The travelling particles: Investigating microplastics as possible transport vectors for multidrug resistant $E$. coli in the Weser estuary (Germany). Science of the Total Environment, 720, 137603. https://doi.org/10.1016/j.scito tenv. 2020.137603 
Strungaru, S. A., Jijie, R., Nicoara, M., Plavan, G., \& Faggio, C. (2019). Micro- (nano) plastics in freshwater ecosystems: Abundance, toxicological impact and quantification methodology. TrAC - Trends in Analytical Chemistry, 110, 116-128. https://doi.org/10.1016/j. trac.2018.10.025

Su, L., Deng, H., Li, B., Chen, Q., Pettigrove, V., Wu, C., \& Shi, H. (2019). The occurrence of microplastic in specific organs in commercially caught fishes from coast and estuary area of east China. Journal of Hazardous Materials, 365, 716-724. https://doi.org/10.1016/j.jhazm at.2018.11.024

Su, L., Nan, B., Hassell, K. L., Craig, N. J., \& Pettigrove, V. (2019). Microplastics biomonitoring in Australian urban wetlands using a common noxious fish (Gambusia holbrooki). Chemosphere, 228, 65-74. https://doi.org/10.1016/j.chemosphere.2019.04.114

Sun, B., Hu, Y., Cheng, H., \& Tao, S. (2019). Releases of brominated flame retardants (BFRs) from microplastics in aqueous medium: Kinetics and molecular-size dependence of diffusion. Water Research, 151, 215-225. https://doi.org/10.1016/j.watres.2018.12.017

Taipale, S. J., Peltomaa, E., Kukkonen, J. V. K., Kainz, M. J., Kautonen, P., \& Tiirola, M. (2019). Tracing the fate of microplastic carbon in the aquatic food web by compound-specific isotope analysis. Scientific Reports, 9, 1-15. https://doi.org/10.1038/s41598-019-55990-2

Thomas, F., Poulin, R., \& Brodeur, J. (2010). Host manipulation by parasites: A multidimensional phenomenon. Oikos, 119, 1217-1223. https://doi.org/10.1111/j.1600-0706.2009.18077.x

Thompson, R. C., Olson, Y., Mitchell, R. P., Davis, A., Rowland, S. J., John, A. W. G., McGonigle, D., \& Russell, A. E. (2004). Lost at sea: Where is all the plastic? Science, 304, 838. https://doi.org/10.1126/scien ce.1094559

Tibbetts, J., Krause, S., Lynch, I., \& Sambrook Smith, G. (2018). Abundance, distribution, and drivers of microplastic contamination in urban river environments. Water, 10, 1597. https://doi. org/10.3390/w10111597

Triebskorn, R., Braunbeck, T., Grummt, T., Hanslik, L., Huppertsberg, S., Jekel, M., Knepper, T. P., Krais, S., Müller, Y. K., Pittroff, M., Ruhl, A. S., Schmieg, H., Schür, C., Strobel, C., Wagner, M., Zumbülte, N., \& Köhler, H.-R. (2019). Relevance of nano- and microplastics for freshwater ecosystems: A critical review. TrAC - Trends in Analytical Chemistry, 110, 375-392. https://doi.org/10.1016/j.trac.2018.11.023

Vendel, A. L., Bessa, F., Alves, V. E. N., Amorim, A. L. A., Patrício, J., \& Palma, A. R. T. (2017). Widespread microplastic ingestion by fish assemblages in tropical estuaries subjected to anthropogenic pressures. Marine Pollution Bulletin, 117, 448-455. https://doi.org/10.1016/j. marpolbul.2017.01.081

Vethaak, A. D., \& Leslie, H. A. (2016). Plastic debris is a human health issue. Environmental Science and Technology, 50, 6825-6826. https:// doi.org/10.1021/acs.est.6b02569

von Friesen, L. W., Granberg, M. E., Pavlova, O., Magnusson, K., Hassellöv, M., \& Gabrielsen, G. W. (2020). Summer sea ice melt and wastewater are important local sources of microlitter to Svalbard waters. Environment International, 139, 105511. https://doi.org/10.1016/j. envint.2020.105511

Walkinshaw, C., Lindeque, P. K., Thompson, R., Tolhurst, T., \& Cole, M. (2020). Microplastics and seafood: lower trophic organisms at highest risk of contamination. Ecotoxicology and Environmental Safety, 190, 110066. https://doi.org/10.1016/j.ecoenv.2019.110066

Walpitagama, M., Carve, M., Douek, A. M., Trestrail, C., Bai, Y., Kaslin, J., $\&$ Wlodkowic, D. (2019). Additives migrating from 3D-printed plastic induce developmental toxicity and neuro-behavioural alterations in early life zebrafish (Danio rerio). Aquatic Toxicology, 213, 105227. https://doi.org/10.1016/j.aquatox.2019.105227

Wan, Z., Wang, C., Zhou, J., Shen, M., Wang, X., Fu, Z., \& Jin, Y. (2019). Effects of polystyrene microplastics on the composition of the microbiome and metabolism in larval zebrafish. Chemosphere, 217, 646-658. https://doi.org/10.1016/j.chemosphere.2018.11.070
Wang, F., Yang, W., Cheng, P., Zhang, S., Zhang, S., Jiao, W., \& Sun, Y. (2019). Adsorption characteristics of cadmium onto microplastics from aqueous solutions. Chemosphere, 235, 1073-1080. https://doi. org/10.1016/j.chemosphere.2019.06.196

Wang, W., Ge, J., \& Yu, X. (2019). Ecotoxicology and environmental safety bioavailability and toxicity of microplastics to fish species: A review. Ecotoxicology and Environmental Safety, 189, 109913. https:// doi.org/10.1016/j.ecoenv.2019.109913

Wang, X., Wei, L., Wang, Y. I., He, B., Kong, B., Zhu, J., Jin, Y., \& Fu, Z. (2019). Evaluation of development, locomotor behavior, oxidative stress, immune responses and apoptosis in developing zebrafish (Danio rerio) exposed to TBECH (tetrabromoethylcyclohexane). Comparative Biochemistry and Physiology Part - C: Toxicology and Pharmacology, 217, 106-113. https://doi.org/10.1016/j.cbpc.2018.12.004

Ward, J. E., Rosa, M., \& Shumway, S. E. (2019). Capture, ingestion, and egestion of microplastics by suspension-feeding bivalves: A 40-year history. Anthropocene Coasts, 2, 39-49. https://doi.org/10.1139/ anc-2018-0027

Watkins, L., McGrattan, S., Sullivan, P. J., \& Walter, M. T. (2019). The effect of dams on river transport of microplastic pollution. Science of the Total Environment, 664, 834-840. https://doi.org/10.1016/j.scito tenv.2019.02.028

Weideman, E. A., Perold, V., \& Ryan, P. G. (2019). Little evidence that dams in the Orange-Vaal River system trap floating microplastics or microfibres. Marine Pollution Bulletin, 149, 110664. https://doi. org/10.1016/j.marpolbul.2019.110664

Wen, B., Jin, S. R., Chen, Z. Z., Gao, J. Z., Liu, Y. N., Liu, J. H., \& Feng, X. S. (2018). Single and combined effects of microplastics and cadmium on the cadmium accumulation, antioxidant defence and innate immunity of the discus fish (Symphysodon aequifasciatus). Environmental Pollution, 243, 462-471. https://doi.org/10.1016/j. envpol.2018.09.029

Wen, B., Zhang, N., Jin, S.-R., Chen, Z.-Z., Gao, J.-Z., Liu, Y., Liu, H.-P., \& Xu, Z. (2018). Microplastics have a more profound impact than elevated temperatures on the predatory performance, digestion and energy metabolism of an Amazonian cichlid. Aquatic Toxicology, 195, 67-76. https://doi.org/10.1016/j.aquatox.2017.12.010

Winkler, A., Santo, N., Ortenzi, M. A., Bolzoni, E., Bacchetta, R., \& Tremolada, P. (2019). Does mechanical stress cause microplastic release from plastic water bottles? Water Research, 166, 115082. https://doi.org/10.1016/j.watres.2019.115082

Wong, G., Löwemark, L., \& Kunz, A. (2020). Microplastic pollution of the Tamsui River and its tributaries in northern Taiwan: Spatial heterogeneity and correlation with precipitation. Environmental Pollution, 260, 113935. https://doi.org/10.1016/j.envpol.2020.113935

Wong, J. K. H., Lee, K. K., Tang, K. H. D., \& Yap, P. S. (2020). Microplastics in the freshwater and terrestrial environments: Prevalence, fates, impacts and sustainable solutions. Science of the Total Environment, 719, 137512. https://doi.org/10.1016/j.scitotenv.2020.137512

Wu, P., Huang, J., Zheng, Y., Yang, Y., Zhang, Y., He, F., Chen, H., Quan, G., Yan, J., Li, T., \& Gao, B. (2019). Environmental occurrences, fate, and impacts of microplastics. Ecotoxicology and Environmental Safety, 184, 109612. https://doi.org/10.1016/j.ecoenv.2019.109612

Wu, P., Tang, Y., Jin, H., Song, Y., Liu, Y., \& Cai, Z. (2020). Consequential fate of bisphenol-attached PVC microplastics in water and simulated intestinal fluids. Environmental Science and Ecotechnology, 2, 100027. https://doi.org/10.1016/j.ese.2020.100027

Xia, X., Sun, M., Zhou, M., Chang, Z., \& Li, L. (2020). Polyvinyl chloride microplastics induce growth inhibition and oxidative stress in Cyprinus carpio var. larvae. Science of the Total Environment, 716, 136479. https://doi.org/10.1016/j.scitotenv.2019.136479

Xiong, X., Tu, Y., Chen, X., Jiang, X., Shi, H., Wu, C., \& Elser, J. J. (2019). Ingestion and egestion of polyethylene microplastics by goldfish (Carassius auratus): Influence of color and morphological features. Heliyon, 5, e03063. https://doi.org/10.1016/j.heliyon.2019.e03063 
Yang, H., Xiong, H., Mi, K., Xue, W., Wei, W., \& Zhang, Y. (2020). Toxicity comparison of nano-sized and micron-sized microplastics to gold fish Carassius auratus larvae. Journal of Hazardous Materials, 388, 122058. https://doi.org/10.1016/j.jhazmat.2020.122058

Yang, L., Qiao, F., Lei, K., Li, H., Kang, Y., Cui, S., \& An, L. (2019). Microfiber release from different fabrics during washing. Environmental Pollution, 239, 136-143. https://doi.org/10.1016/j.envpol.2019.03.011

Young, N. D., Dyková, I., Nowak, B. F., \& Morrison, R. N. (2008). Development of a diagnostic PCR to detect Neoparamoeba perurans, agent of amoebic gill disease. Journal of Fish Diseases, 31, 285-295. https://doi.org/10.1111/j.1365-2761.2008.00903.x

Yu, Y., Ma, R., Qu, H., Zuo, Y., Yu, Z., Hu, G., Li, Z., Chen, H., Lin, B., Wang, B., \& Yu, G. (2020). Enhanced adsorption of tetrabromobisphenol a (TBBPA) on cosmetic-derived plastic microbeads and combined effects on zebrafish. Chemosphere, 248, 126067. https://doi. org/10.1016/j.chemosphere.2020.126067

Yuan, W., Liu, X., Wang, W., Di, M., \& Wang, J. (2019). Microplastic abundance, distribution and composition in water, sediments, and wild fish from Poyang Lake, China. Ecotoxicology and Environmental Safety, 170, 180-187. https://doi.org/10.1016/j. ecoenv.2018.11.126

Yukioka, S., Tanaka, S., Nabetani, Y., Suzuki, Y., Ushijima, T., Fujii, S., Takada, H., Van Tran, Q., \& Singh, S. (2019). Occurrence and characteristics of microplastics in surface road dust in Kusatsu (Japan), Da Nang (Vietnam), and Kathmandu (Nepal). Environmental Pollution, 256, 113447. https://doi.org/10.1016/j.envpol.2019.113447

Yurtsever, M. (2019). Glitters as a source of primary microplastics: An approach to environmental responsibility and ethics. Journal of Agricultural and Environmental Ethics, 32, 459-478. https://doi. org/10.1007/s10806-019-09785-0

Zhang, K., Xiong, X., Hu, H., Wu, C., Bi, Y., Wu, Y., Zhou, B., Lam, P. K. S., \& Liu, J. (2017). Occurrence and characteristics of microplastic pollution in Xiangxi Bay of Three Gorges Reservoir, China. Environmental Science and Technology, 51, 3794-3801. https://doi.org/10.1021/acs. est.7b00369
Zhang, Y., Gao, T., Kang, S., \& Sillanpää, M. (2019). Importance of atmospheric transport for microplastics deposited in remote areas. Environmental Pollution, 254, 1-4. https://doi.org/10.1016/j. envpol.2019.07.121

Zhang, Y., Kang, S., Allen, S., Allen, D., Gao, T., \& Sillanpää, M. (2020). Atmospheric microplastics: A review on current status and perspectives. Earth-Science Reviews, 203, 103118. https://doi.org/10.1016/j. earscirev.2020.103118

Zhang, Z., \& Chen, Y. (2019). Effects of microplastics on wastewater and sewage sludge treatment and their removal: A review. Chemical Engineering Journal, 382, 122955. https://doi.org/10.1016/j. cej.2019.122955

Zhao, Y., Bao, Z., Wan, Z., Fu, Z., \& Jin, Y. (2020). Polystyrene microplastic exposure disturbs hepatic glycolipid metabolism at the physiological, biochemical, and transcriptomic levels in adult zebrafish. Science of the Total Environment, 710, 136279. https://doi.org/10.1016/j.scito tenv.2019.136279

Zheng, K., Fan, Y., Zhu, Z., Chen, G., Tang, C., \& Peng, X. (2019). Occurrence and species-specific distribution of plastic debris in wild freshwater fish from the Pearl River catchment, China. Environmental Toxicology and Chemistry, 38, 1504-1513. https://doi.org/10.1002/ etc.4437

Zink, L., \& Pyle, G. G. (2019). Contrary to marine environments, common microplastics in freshwater systems may not emit dimethyl sulfide: An important infochemical. Bulletin of Environmental Contamination and Toxicology, 103, 766-769. https://doi.org/10.1007/s00128-01902726-7

How to cite this article: Parker B, Andreou D, Green ID, Britton JR. Microplastics in freshwater fishes: Occurrence, impacts and future perspectives. Fish Fish. 2021;22:467-488. https:// doi.org/10.1111/faf.12528 